\title{
AVALIAÇÃO DOS EFEITOS DO INSETICIDA-ACARICIDA CLORFENAPIR (PIRROLE) SOBRE O ÁCARO DA LEPROSE, Brevipalpus phoenicis (Geijskes, 1939), ATRAVÉS DE NOVA METODOLOGIA PARA BIOENSAIOS
}

\section{Rubens Mazzilli Louzada \\ Engenheiro Agrônomo}

Orientador: Prof. Dr. Octávio Nakano

Dissertação apresentada à Escola Superior de Agricultura "Luiz de Queiroz", Universidade de São Paulo, para obtenção do título de Mestre em Ciências, Área de Concentração: Entomologia.

\section{PIRACICABA}

Estado de São Paulo - Brasil

$$
\text { Janeiro - } 1998
$$


Dados Internacionais de Catalogação na Publicação (CIP)

DIVISÃo DE BIBLIOTECA E DOCUMENTAÇÃO - Campus "Luiz de Queiroz"/USP

Louzada, Rubens Mazzilli

Avaliaçao dos efeitos do insetecida-acaricida clorfenapir (Pirrole) sobre o ácaro da leprose, Brevipalpus phoenicis (Geijskes, 1939), através de nova metodologia para bioensaios / Rubens Mazzilli Louzada. - - Piracicaba, 1998.

63 p. : il.

Dissertação (mestrado) - - Escola Superior de Agricultura Luiz de Queiroz, 1998. Bibliografia.

1. Acaricida 2. Ácaro 3. Controle químico 4. Ensaio biológico 5. Leprose citrica I. Título 
AVALIAÇÃO DOS EFEITOS DO INSETICIDA-ACARICIDA CLORFENAPIR (PIRROLE) SOBRE O ÁCARO DA LEPROSE, Brevipalpus phoenicis (Geijskes, 1939), ATRAVÉS DE NOVA METODOLOGIA PARA BIOENSAIOS

Aprovada em: 16/04/98

Comissão julgadora:

Prof. Dr. Octávo Nakano

ESALQ/USP

Prof. Dr. Celso Omoto

ESALQ/USP

Prof ${ }^{a}$. Dr ${ }^{\mathrm{a}}$. Neuza de Lima Nogueira

CENA/USP

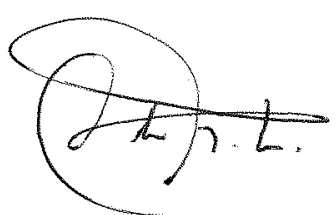

Prof. Dr. Octávio Nakano

Orientador 
Aos meus pais Aroldo, in memoriam, e Jane, à minha mulher, Bartira, e às minhas filhas Laura e Stella, geradores de sentimento, conhecimento, espiritualidade, enfim, da vida, todos, razão da minha existência

\section{DEDICO}

A Deus, energia criadora

\section{AGRADECO}




\section{AGRADECIMENTOS}

Ao Dr. Octávio Nakano, Professor Titular do Departamento de Entomologia da Escola Superior de Agricultura "Luiz de Queiroz", Universidade de São Paulo (ESALQ/USP), pela confiança, orientação e apoio na realização desse trabalho.

Aos professores do curso de pós-graduação do Departamento de Entomologia ESALQ, USP, pelos ensinamentos transmitidos e orientação na condução dos trabalhos ao longo de todo o curso, em especial aos professores José Roberto Postali Parra e Celso Omoto.

Ao prof. Dr. Carlos Tadeu dos Santos Dias do Departamento de Matemática e Estatística da ESALQ/USP e Marcelo Corrêa Alves, funcionário do CIAGRI ESALQ/USP , pelo auxílio na execução da análise estatística.

A todos os colegas e companheiros de mestrado e doutorado que ao longo do curso nos apoiaram e em muitas situações forneceram a energia necessária para a conclusão desse trabalho, em especial aos amigos Alberto, Marcelo, Reginaldo, Charles, Maria Aparecida e Geraldo.

As bibliotecárias Eliana Maria Garcia Sabino e Kátia Maria de Andrade Ferraz, que ao longo de todo o curso sempre esclareceram as minhas dúvidas, neste fascinante $\mathrm{e}$ complexo mundo, que é uma biblioteca. 
A todos os amigos e funcionários do Departamento de Entomologia e da Biblioteca Central, que colaboraram para a execução desse trabalho.

À Coordenadoria de Aperfeiçoamento de Pessoal de Nível Superior - CAPES, pela bolsa de estudo concedida.

À Cyanamid Química do Brasil Ltda, representada pelo Sr. Kenji Utsumi, que acreditou nesse trabalho, dando suporte financeiro para a sua execução.

Aos agricultores Amauri Antonio Malagoni e Domingos Virecoulon que colocaram as suas propriedades à disposição, contribuindo para a execução deste trabalho.

A todos que direta ou indiretamente contribuíram para a realização desse trabalho. 


\section{SUMÁRIO}

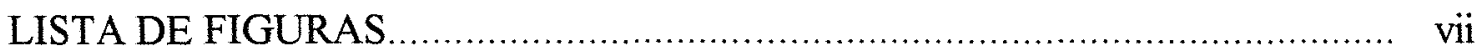

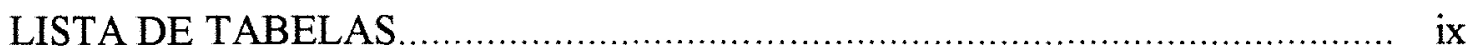

RESUMO

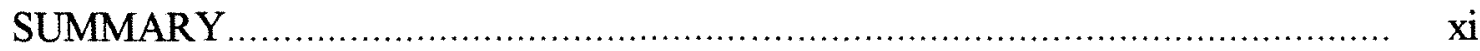

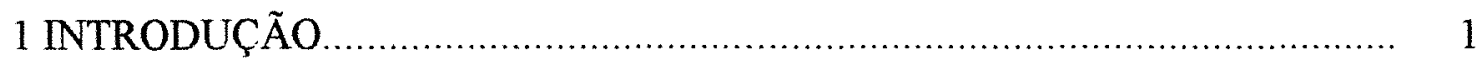

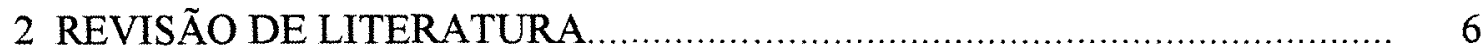

2.1 Histórico e distribuição geográfica do ácaro da leprose dos citros Brevipalpus phoenicis (Geijskes, 1939) ............................................................... 6

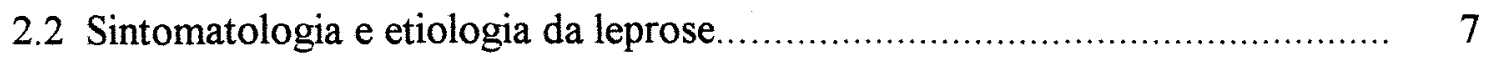

2.3 Aspectos bio-ecológicos e metodologia de criação........................................ 10

2.4 Avaliação de danos e medidas de controle ................................................. 14

2.5 Informações sobre o clorfenapir (Citrex 24 SC) …...................................... 16

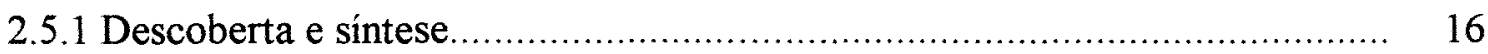

2.5.2 Propriedades fisicas e químicas......................................................... 17

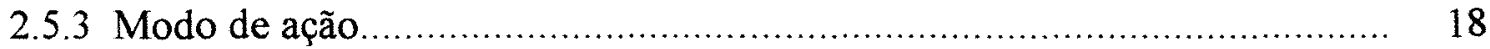

2.5.4 Dados toxicológicos.................................................................... 18

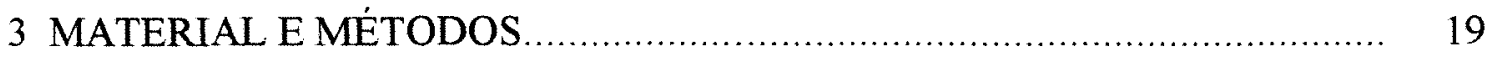

3.1 Coleta e manutenção de Brevipalpus phoenicis no laboratório........................ 20

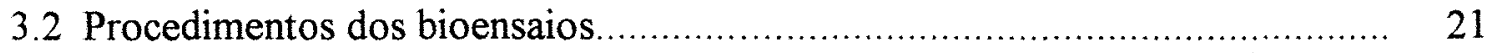

3.2.1 Bioensaio com aplicação do clorfenapir através do método de imersão........ 23

3.2.2 Bioensaio com aplicação através de imersão, com a mistura de gesso e areia tratada (GT) e não tratada (GNT) com o clorfenapir

3.2.3 Bioensaio com pulverização dos acaricidas através da Torre de Potter ........ 24 


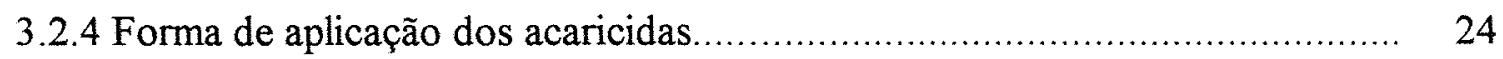

3.3 Metodologia das avaliações................................................................ 25

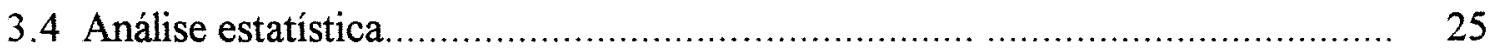

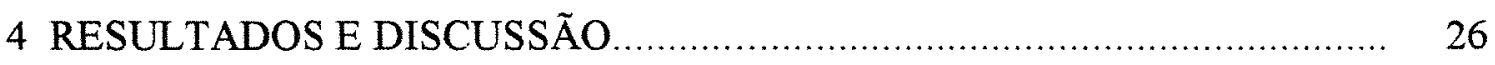

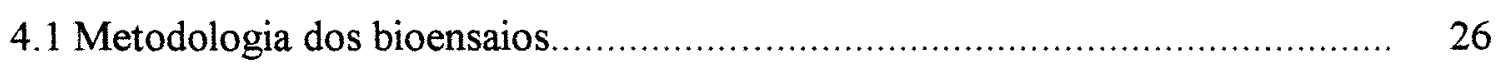

4.2 Comportamento da fềmea na postura............................................................. 27

4.3 Bioensaio com aplicação do clorfenapir através do método de imersão........... 28

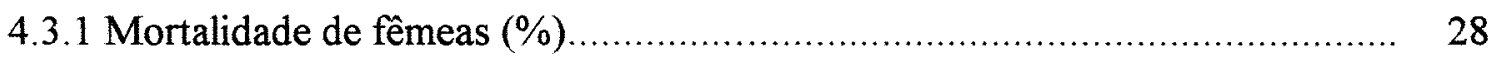

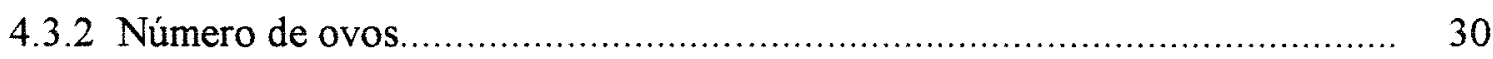

4.3.3 Número de larvas vivas..................................................................... 31

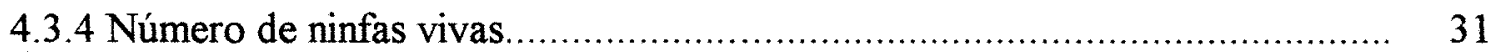

4.4 Bioensaio com aplicação através da imersão, com a mistura de gesso e areia tratada (GT) e não tratada (GNT) com o clorfenapir

4.4.1 Mortalidade de fềmeas (\%) .............................................................. 33

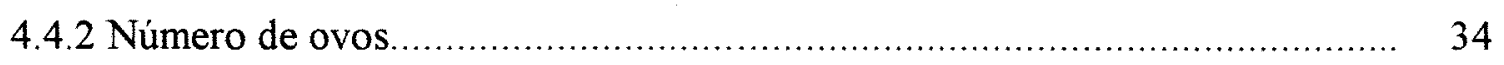

4.4.3 Número de larvas mortas ................................................................ 34

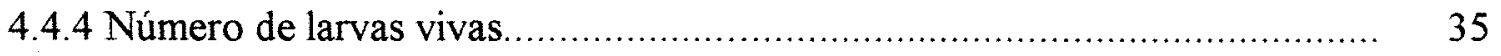

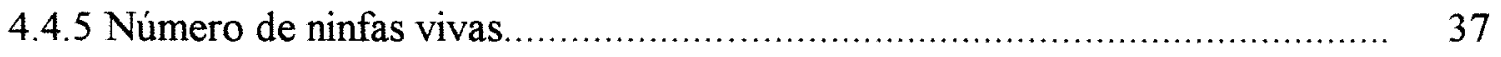

4.4.6 Número de adultos da $1^{\mathrm{a}}$ geração............................................................. 37

4.5 Bioensaio com pulverização dos acaricidas através da Torre de Potter ............ 38

4.5.1 Mortalidade de fềmeas (\%) .............................................................. 38

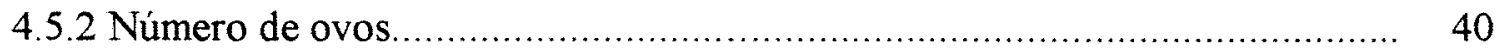

4.5.3 Número de larvas mortas................................................................. 41

4.5.4 Número acumulado de larvas mortas................................................... 42 
4.5.5 Número de larvas vivas........................................................ 43

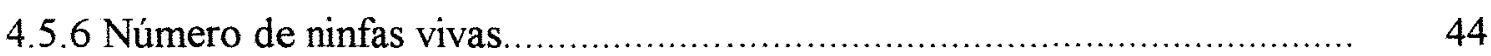

4.5.7 Número de adultos da $1^{\mathrm{a}}$ geração.................................................. 45

4.6 Aplicação prática dos resultados obtidos nos três bioensaios...................... 45

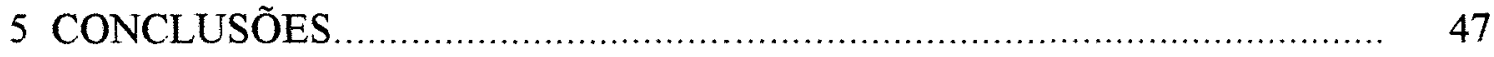

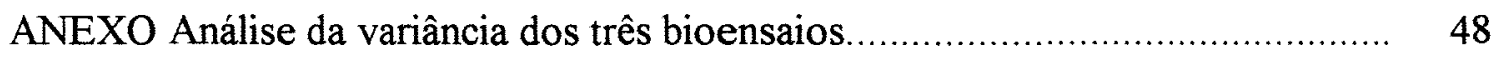

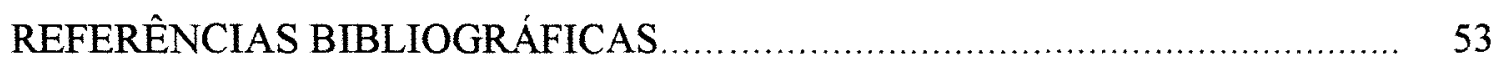




\section{LISTA DE FIGURAS}

Figura Título

Página

1 Termohigrômetros digitais utilizados nas leituras de temperatura e umidade

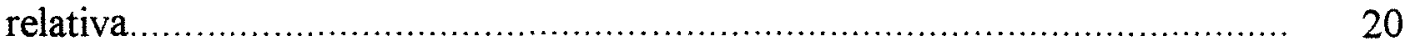

2 Fruto preparado para receber as fềmeas adultas do ácaro da leprose............ 22

3 Detalhe do fruto preparado com o gesso e areia, onde observam-se as fềmeas adultas, larvas, ninfas e ovos de Brevipalpus phoenicis.................. 27

4 Mortalidade de fềmeas (\%), bioensaio de imersão........................................ 29

$5 \quad$ Número médio de ovos, bioensaio de imersão..................................... 30

6 Número médio de larvas vivas, bioensaio de imersão................................... 31

$7 \quad$ Número médio de ninfas vivas, bioensaio de imersão .................................... 32

8 Mortalidade de fềmeas (\%), bioensaio de imersão com gesso tratado e não tratado com o clorfenapir..................................................................... 33

9 Número médio de ovos, bioensaio de imersão com gesso tratado e não tratado com o clorfenapir.

10 Número médio de larvas mortas, bioensaio de imersão com gesso tratado e não tratado com o clorfenapir.

11 Número médio de larvas vivas, bioensaio de imersão com gesso tratado e não tratado com o clorfenapir.

12 Número médio de ninfas vivas, bioensaio de imersão com gesso tratado e não tratado com o clorfenapir.

13 Número médio de adultos da $1^{a}$ geração, bioensaio de imersão com gesso tratado e não tratado com o clorfenapir.

14 Mortalidade de fềmeas (\%), bioensaio com pulverização através da Torre de Potter

15 Número médio de ovos, bioensaio com pulverização através da Torre de Potter.

16 Número médio de larvas mortas, bioensaio com pulverização através da Torre de Potter 
17 Número médio acumulado de larvas mortas, bioensaio com pulverização através da Torre de Potter.

18 Número médio de larvas vivas, bioensaio com pulverização através da Torre de Potter.

19 Número médio de ninfas vivas, bioensaio com pulverização através da Torre de Potter.

20 Número médio de adultos da $1^{a}$ geração, bioensaio com pulverização através da Torre de Potter..... 


\section{LISTA DE TABELAS}

Tabela

Título

Página

1 Toxicidade aguda do clorfenapir para mamíferos.

18

2 Tratamentos aplicados através do método de imersão

23

3 Tratamentos aplicados através do método de imersão, com a mistura de gesso e areia tratada (GT) e não tratada (GNT) com o clorfenapir.

4 Tratamentos pulverizados através da Torre de Potter. 


\section{AVALIAÇÃO DOS EFEITOS DO INSETICIDA-ACARICIDA CLORFENAPIR (PIRROLE) SOBRE O ÁCARO DA LEPROSE, Brevipalpus phoenicis (Geijskes, 1939), ATRAVÉS DE NOVA METODOLOGIA PARA BIOENSAIOS}

Autor: Rubens Mazzilli Louzada

Orientador: Prof. Octávio Nakano

\section{RESUMO}

Com o objetivo de testar os efeitos de doses sub-letais do inseticida-acaricida clorfenapir (Citrex 24SC), pertencente ao novo grupo químico conhecido por pirroles, sobre adultos, larvas, ninfas e ovos do ácaro da leprose Brevipalpus phoenicis (Geijskes, 1939), uma nova metodologia para a condução de bioensaios foi desenvolvida. Os bioensaios foram conduzidos em uma arena montada sobre o fruto da laranja utilizandose água como barreira, que delimitou a área onde os ácaros permaneceram no fruto durante a condução dos testes. A água substituiu o Tanglefoot ${ }^{\mathbb{R}}$, adesivo normalmente usado para esta finalidade, proporcionando um ambiente estável e constante para o desenvolvimento dos ácaros, além de diminuir a mortalidade e impedir a fuga de ácaros. Os frutos foram tratados com os acaricidas através de dois métodos distintos: imersão e pulverização em Torre de Potter. A metodologia foi eficiente para a condução dos bioensaios e permitiu concluir que a dosagem de 1,92 g i.a. $/ 100 \mathrm{~L}$, mesmo causando três semanas após a aplicação dos tratamentos, mortalidade média de fềmeas de $89 \%$ nos três bioensaios, foi a mais adequada para avaliar os efeitos do clorfenapir na população remanescente de B. phoenicis. 
EVALUATION OF THE CHLORFENAPYR INSECTIDE-ACARICIDE EFFECTS (PYRROLE) ON THE LEPROSIS MITE Brevipalpus phoenicis (Geijskes, 1939), THROUGH A NEW BIOASSAY METODOLOGY

Author: Rubens Mazzilli Louzada

Adviser: Prof. Octávo Nakano

\section{SUMMARY}

With the purpose of testing the effects of the insecticide-acaricide chlorfenapyr (Citrex 24SC), which belongs to a new chemical group known as Pyrroles, on the adults, larvae, ninphs and eggs of the leprosis mite Brevipalpus phoenicis (Geijskes, 1939), a new methodology for bioassays has been developed. The bioassays were conducted on an arena assembled over orange fruits, in an adaptation of the methodology used by Chiavegato (1986) in biology and lab control trials. Water was used as a barrier in replacement for Tanglefoot ${ }^{R}$, thus providing stable environment for development of mites, in addition to preventing them from escaping. The fruits were treated through two distinct methods: immersion in acaricide solutions at different concentrations and Potter Tower spraying. The methodology has led to the conclusion that the dosage of $1.92 \mathrm{~g} \mathrm{a}$. i. $/ 100 \mathrm{~L}$, although causing $89 \%$ of female mortality three weaks after treatment in the three bioassay, was the most adequate to assess the effects of chlorfenapyr on $B$. phoenicis remaining population. 


\section{INTRODUÇÃO}

A importância da citricultura é muito grande tanto para o estado de São Paulo como para outros estados do Brasil, seja pela receita gerada pelas exportações de suco concentrado, que tem o Brasil como o maior produtor e exportador, seja pelo grande número de empregos e serviços que gera durante todo o processo produtivo desde o plantio até a comercialização e industrialização da fruta.

Problemas fitossanitários associados a técnicas culturais inadequadas fazem com que a produtividade brasileira seja uma das mais baixas do mundo, apesar das condições favoráveis existentes para o desenvolvimento da cultura em quase todo o país (Boaretto et al. 1993). Os danos causados pelo ácaro da leprose Brevipalpus phoenicis (Geijskes, 1939) destacam-se entre os fatores mais importantes relacionados a essas perdas, principalmente porque em muitas vezes o seu controle tem se mostrado ineficiente. Dados da ANDEF (Associação Nacional de Defesa Vegetal), citados por Salvo Filho (1997), mostram que anualmente, gastam-se 90 milhões de dólares com o controle dos principais ácaros dos citros, sendo cerca de 75 milhões apenas com o controle da leprose, calculando-se que $10 \%$ desses tratamentos são perdidos devido a má aplicação dos defensivos. Dados da ANDEF de 1989, citados por Salvo \& Salvo (1991), mostravam que os citricultores do estado de São Paulo gastavam 120 milhões de dólares com tratamentos fitossanitários, sendo $50 \%$ desse valor representado por gastos com a leprose, o que demonstra um aumento significativo de despesas com essa praga. Cabrita (1987) afirmou que mais de 50\% do custo de produção de frutas cítricas é representado pelo tratamento fitossanitário. $\mathrm{O}$ valor despendido apenas com os acaricidas pode chegar 
a até $56 \%$ do custo de produção (Gravena, 1992). Rodrigues et al. (1994), afirmaram que a importância da retomada da leprose, entre outros, pode ser devido a aplicações excessivas e inadequadas de agroquímicos, que podem estar contribuindo para a diminuição dos inimigos naturais do vetor.

Muitos são os trabalhos de campo realizados visando o controle do ácaro da leprose, onde se utilizam uma variada gama de acaricidas, porém seu controle químico tem se mostrado dificil, sendo poucos os agrotóxicos realmente eficientes no combate a esta importante praga e que satisfaçam as exigências de um correto manejo da cultura (Myazaki et al. 1982, Oliveira et al. 1983, Calafiori et al. 1986, Nakano 1986, Raga et al. 1990, Scarpellini et al. 1991, Vendramini et al. 1993). A ineficiência do controle depende de uma série de fatores, entre eles a utilização de sub-dosagens, número insuficiente de aplicações, cobertura parcial da planta, aplicações fora de época e até mesmo aplicação de agrotóxicos com prazo de validade vencido e a possibilidade de desenvolvimento da resistência de B. phoenicis a certos acaricidas (Suplicy Filho et al., 1977). A aplicação de produtos químicos ainda tem sido o principal método de controle para manter a densidade populacional dessa praga abaixo dos niveis de dano, sendo que a hipótese da existência de resistência também foi considerada por Chiavegato (1987) e Nakano (1995), que creditaram o seu aparecimento provavelmente devido às constantes pulverizações com produtos do mesmo grupo químico. Gravena (1994) detectou diferenças na susceptibilidade de populações de B. phoenicis ao dicofol, em pomares no estado de São Paulo. Apesar da importância desse problema, poucos são os estudos nesta área no Brasil, existindo vários fatores que favorecem o desenvolvimento da resistência de $B$. phoenicis à acaricidas, como, por exemplo, a reprodução predominante por partenogênese telítoca, o reduzido número de cromossomos $(n=2)$ e a meiose invertida. Para comprovação do problema da resistência, há necessidade urgente de iniciar um programa de deteç̧ão e monitoramento da resistência de $B$. phoenicis aos principais acaricidas recomendados para o seu controle (Omoto, 1996). 
Nos últimos anos tem-se procurado a implantação de um programa de manejo integrado de pragas (MIP) cítricas, cuja base é a preservação de inimigos naturais, constituidos principalmente de ácaros predadores, sendo necessária a utilização de agrotóxicos, cada vez menos tóxicos. A eficiência desses pesticidas e seus efeitos aos inimigos naturais foram analisados por diversos autores (Gravena \& Lara 1976, Komatsu \& Nakano 1988, Scarpellini \& Nakano 1989, Sato et al. 1991, Sato et al. 1992). Entre os avanços alcançados na pesquisa e na prática do MTP na citricultura, destacam-se o manejo ambiental, a amostragem sequencial e as inovações que poderão ser alcançadas com o controle biológico de pragas, sendo que somente uma visão global, espacial e temporal dos beneficios do sistema, possibilitará a seleção segura de táticas que apresentem vantagens para o sistema como um todo, integrando um complexo interrelacionado com um custo-risco benéfico, calculado sob o ponto de vista econômico, ecológico e social ao mesmo tempo (Gravena, 1992).

No Brasil poucos são os trabalhos de controle do ácaro da leprose em laboratório, devido principalmente a dificuldade de sua criação. No entanto, dados de eficiência nessa condição são extremamente importantes nos estudos dos acaricidas, pois as condições micro-climáticas são passíveis de controle e próximas as ideais ao desenvolvimento dos ácaros. Os bioensaios podem ser conduzidos ao longo de todo o ano, a um custo inferior dos ensaios de campo, não estando sujeitos à condições climáticas adversas. Mas, apenas os bioensaios não são suficientes aos estudos de controle e eficiência de inseticidas ou acaricidas, embora constituam-se em uma importante ferramenta em projetos de pesquisa e desenvolvimento de um novo produto, devendo ser complementados com ensaios de casa de vegetação e campo.

Com o objetivo de testar os efeitos de doses sub-letais do inseticida-acaricida clorfenapir (Citrex 24SC), pertencente ao novo grupo químico dos pirroles, sobre a progênie do ácaro da leprose $B$. phoenicis, uma nova metodologia para a condução de bioensaios foi desenvolvida e testada em três experimentos. Os bioensaios foram realizados em uma arena montada sobre os frutos de laranja, adaptando-se a metodologia 
desenvolvida por Chiavegato (1986), utilizada em testes de controle e biologia em laboratório.

Nos testes preliminares foi utilizada como barreira o Tanglefoot ${ }^{\mathrm{R}}$, adesivo que não apresentou resultados satisfatórios, pois muitos ácaros morreram grudados neste tipo de cola, alcançando em alguns tratamentos mais de 50\% de mortalidade, confirmando os dados obtidos por Chiavegato (1972 e 1986), Nakano et al. (1987) e Albuquerque el al. (1995), que verificaram que este fato dificulta ou até mesmo impossibilita a conclusão de ensaios em laboratório. A mudança da barreira do Tanglefoot ${ }^{\mathrm{R}}$, para a água destilada diminuiu significativamente os índices de mortalidade das fềmeas.

Esses testes mostraram que a dosagem de $7,5 \mathrm{~g}$ i. a./100 L, ou seja, $50 \%$ da recomendada pelo fabricante do acaricida, controlou de 90 a $100 \%$ da população de ácaros presentes nos frutos. Como um dos objetivos desse trabalho foi estudar os efeitos do clorfenapir sobre a população de fềmeas sobreviventes e formas ativas oriundas de sua postura, e na dosagem de $3,0 \mathrm{~g}$ i. a. $/ 100 \mathrm{~L}$, aos $21 \mathrm{DAI}$, a mortalidade de adultos e larvas foi de $91,7 \%$ e $96,8 \%$ respectivamente, esta foi a dosagem que serviu de base para este estudo.

Nos testes preliminares além do clorfenapir e do óxido de fenbutatin, considerado por Yamamoto et al. (1992), como um dos nove produtos mais utilizados na citricultura no controle dos ácaros, foi testado o inseticida-acaricida Rufast $5 \mathrm{SC}$, que devido a sua alta repelência aos ácaros foi descartado logo no primeiro bioensaio. Como o óxido de fenbutatin, na dosagem recomendada pelo fabricante, alcançou índices de mortalidade de fêmeas da ordem de 100\%, esse produto foi utilizado apenas no bioensaio onde os acaricidas foram aplicados utilizando-se a Torre de Potter.

A dificuldade de condução de bioensaios está relacionada a mortalidade do ácaro, que foi pequena nos três bioensaios variando de $10 \%$ a $16 \%$, na primeira semana após a aplicação dos tratamentos, o que propiciou a condução dos bioensaios. 
A metodologia foi eficiente para a condução dos bioensaios e permitiu concluir que a dosagem de $1,92 \mathrm{~g}$ i.a. $/ 100 \mathrm{~L}$, mesmo causando três semanas após a aplicação dos tratamentos, mortalidade média de fềmeas de $89 \%$ nos três bioensaios, foi a mais adequada para avaliar os efeitos do clorfenapir na população remanescente de $B$. phoenicis. 


\section{REVISÃO DE LITERATURA}

\subsection{Histórico e distribuição geográfica do ácaro da leprose dos citros Brevipalpus phoenicis}

Fawcett (1936) refere-se a ocorrência da leprose em diferentes partes do mundo, incluindo países da Ásia, apresentando importância secundária na China, tendo sido registrada na África do Sul e Egito. Nos EUA ela foi relatada pelo primeira vez na Flórida, no final do século XIX, atacando principalmente ramos de citros. A distribuição cosmopolita do ácaro da leprose foi constatada por Knorr \& Denmark (1970), sendo encontrado na Flórida, Texas, México, Cuba, Trinidad, Argentina, Brasil, Venezuela, Aden, Etiópia, Egito, Espanha, Síria, Índia e Filipinas.

$\mathrm{O}$ ácaro da leprose Brevipalpus phoenicis foi descrito pela primeira vez por Geijskes em 1939 na Holanda, atacando Phoenix em casa de vegetação, sendo denominado de Tenuipalpus phoenicus. O local preciso de sua origem, devido a sua ampla distribuição geográfica, não foi possível de ser determinado, devendo ser tropical e associado a ácaros do gênero Brevipalpus (Haramoto, 1969).

Knorr (1950), na Flórida e Musumeci \& Rosseti (1963), no Brasil associaram a ocorrrência da leprose a Brevipalpus californicus e B. phoenicis respectivamente.

Oliveira (1986) relatou a ocorrência de B. phoenicis nos estados de Santa Catarina, São Paulo, Minas Gerais, Bahia, Pernambuco, Rio Grande do Norte e Ceará, afirmando que este ácaro deve ocorrer em vários outros estados, devido ao grande número de espécies vegetais em que ele pode se hospedar. 
Chiavegato (1987) verificou que desde 1978, quando se iniciou o levantamento do ácaro da leprose no estado de São Paulo, cerca de 6.000 lâminas foram examinadas, sendo identificadas como sendo de B. phoenicis. No entanto o autor faz referência a variações observadas na reticulação no propodossoma e no comprimento das setas dorsais de alguns ácaros. Trindade \& Chiavegato (1994) relataram a presença de $B$. phoenicis em 34 hospedeiros distintos em diferentes regiões do estado de São Paulo, infestando plantas cultivadas, ornamentais e plantas daninhas dos pomares cítricos .

\subsection{Sintomatologia e etiologia da leprose}

A leprose manifesta-se nos ramos através de pequenas manchas, ligeiramente salientes, arredondadas de coloração amarela ou verde palha. Posteriormente os tecidos tornam-se marrom avermelhados ou chocolate, ocorrendo a seca dos mesmos, podendo em algumas situações destacarem-se em pequenas escamas. As folhas apresentam manchas com 4 a $12 \mathrm{~mm}$ de diâmetro, ligeiramente arredondadas, salientes na superficie inferior e lisas na superior, com coloração verde palha no centro e amarelada na periferia. Ocorre posterior necrose e seca destes tecidos que adquirem coloração parda. Nos frutos, as manchas começam a aparecer quando estes medem de 4 a $5 \mathrm{~cm}$ de diâmetro, sob a forma de pequenas manchas amarelas com centro mais escuro, apresentando uma auréola amarela, ocorrendo uma depressão na casca nos frutos mais maduros (Bitancourt, 1940).

Descrições semelhantes desses sintomas foram feitas por Guirado \& Silvério (1992). Esses autores relataram os sintomas iniciais nos ramos como lesões inicialmente amareladas, tornando-se mais tarde salientes e corticosas. O grande número destas lesões acarreta a morte dos ponteiros, podendo levar a planta à morte. Knorr \& Denmark (1970) descreveram a clorose nas folhas e a sua queda como o principal sintoma da doença. Ochoa \& Salas (1989) descreveram os sintomas causados pelo Brevipalpus como cloroses, necroses, estrias na superficie dos frutos e mal formação dos mesmos, 
sendo que os danos são maiores quando estão associados às doenças e ataque de outros insetos ou ácaros.

Bitancourt (1955 e 1956) em 1931 observou manchas típicas de leprose em folhas de laranja doce da variedade Bahia, procedentes de Sorocaba, atribuindo aos sintomas o nome de variola. Estabelecendo em 1932-1933 que se tratava da leprose, apesar de existirem algumas diferenças em relação aos sintomas observados em outras regiões do estado de São Paulo e da Flórida. O autor verificou que esses sintomas variam de acordo com a variedade, localidade e fase de desenvolvimento do órgão afetado.

Roessing \& Salibe (1967) verificaram a susceptibilidade à leprose de diferentes variedades e espécies do gênero Citrus e observaram diferenças na intensidade de ataque e nos sintomas em 130 dos 369 materiais analisados.

Knorr et al. (1968) descreveram a doença na Argentina e no Paraguai como lepra explosiva, verificando em seguida tratar-se da mesma doença observada pela primeira vez na Flórida na década de 1860. O mesmo autor demonstrou na Flórida que o ácaro Brevipalpus obovatus Donn. induziu sintomas da leprose mesmo quando coletado em Bidens pilosa L., planta não susceptivel ao vírus, ou em áreas geográficas onde não se conhecia a leprose.

Musumeci \& Rosseti (1963) infestaram mudas sadias de laranja Pêra com ácaros provenientes de ramos, folhas e frutos com sintomas da leprose e obtiveram a reprodução dos sintomas, que apareceram de quatro meses e meio até oito meses após as infestações, concluindo que $B$. phoenicis é o responsável pela transmissão da leprose no estado de São Paulo. Boaretto et al. (1993) infestaram mudas de laranjeiras Pêra-Rio e Hamlim e "seedlings" de Hamlin, com fêmeas de B. phoenicis, encontrando períodos menores para a manifestação dos sintomas, observando as primeiras alterações na coloração das folhas aos 19 dias, constatando a presença de pontuações amareladas com centro marrom escuro 28 dias após a infestação. Os primeiros sintomas apareceram nos "seedlings", pois os tecidos mais jovens apresentam condições favoráveis ao desenvolvimento das lesões 
da leprose. Rosseti et al. (1965) verificaram que além dos sintomas da leprose $B$. phoenicis pode provocar manchas em folhas conhecidas como clorose zonada, que aparecem de 20 a 40 dias após a infestação. Chagas (1973) atribuiu ao ácaro B. phoenicis a transmissão da mancha anular do cafeeiro, que possui sintomas muito semelhantes à leprose dos citros.

Chagas \& Rosseti (1980), trabalhando com enxertia de mudas de laranja caipira, verificaram a possibilidade da passagem da doença por meios mecânicos, na ausência de ácaros, o que tende a mostrar a etiologia viral da doença, fato confirmado por Kitajima et al. (1971), que reforçaram essa teoria ao relatar a ocorrência de partículas semelhantes ao vírus do tipo "rhabdovirus", nos tecidos das lesões da leprose. Colariccio (1996) observando cortes ultrafinos de amostras de folhas de citros infectados pela leprose, detectou partículas baciliformes, sem envelope, confinadas em cisternas do retículo endoplasmático, sugerindo que o CiLV ("citrus leprosis virus") representa um "rhabdovirus" não envelopado. Segundo Guirado \& Silvério (1992) e Rosseti et al. (1993) a leprose dos citros, transmitida por B. phoenicis, é possivelmente, a doença atribuída a vírus mais importante nos pomares do estado de São Paulo.

Boaretto \& Chiavegato (1994) verificaram que um período de alimentação de seis dias em folhas sadias é suficiente para que o ácaro da leprose transmita o agente causal da doença para folhas de laranjeira azeda. B. phoenicis alimentando-se quatro dias, em citros e cafeeiro adquiriu o vírus, não sendo necessário alimentar-se nas lesões. Os sintomas predominantes nas folhas foram cloroses.

Chiavegato \& Salibe (1981) concluíram que ácaros inicialmente não contaminados adquirem o agente causal da leprose alimentando-se de folhas já contaminadas por um período de quatro dias e que o período de dois dias é suficiente para que eles passem a transmitir a leprose. Verificaram também que $B$. phoenicis mantém a capacidade de transmitir a leprose quando transferido de uma folha sadia para outra, não sendo 
necessário alimentar-se em lesões típicas da doença, mas apenas em folhas previamente infestadas com ácaros contaminados.

Rodrigues (1995) pesquisou aspectos relacionados com a cito-histopatologia dos tecidos foliares de laranjeira, concluindo que o ácaro B. phoenicis é o agente transmissor da leprose dos citros, induzindo alterações histo-citológicas nos tecidos foliares da laranjeira.

\subsection{Aspectos bio-ecológicos do ácaro da leprose e metodologia de criação}

O ácaro da leprose durante o seu ciclo evolutivo passa pelos estádios de ovo, larva, protoninfa, deutoninfa e adulto. Sua reprodução pode acontecer de forma assexuada, por partenogênese telítoca e sexuada com concurso dos machos, que são muito raros. Apesar das semelhanças existentes entre a protoninfa e a deutoninfa, a diferenciação entre esses estádios é possível de ser efetuada com auxilio de um microscópio estereoscópico (Hatzinikolis, 1986, Gonzales, 1975). A frequência de machos é baixa, fato relatado por Helle e Bolland (1972), citados por Pijnaker et al. (1981), e a diferenciação entre os sexos é possível de ser efetuada. Os machos tem o corpo afilado posteriormente e não apresenta as manchas escuras (Flechtmann et al., 1995), característica das fêmeas, que tem a pigmentação preta aumentada de acordo com seu desenvolvimento e alimentação (Morishita, 1954; Haramoto, 1969; Gonzales, 1975).

A temperatura tem grande influência sobre o ciclo biológico de Brevipalpus, sendo seus efeitos observados por diversos pesquisadores em condições de hospedeiros distintos. Morishita (1954) criou o ácaro Brevipalpus inornatus, em folhas de violeta, durante aproximadamente 20 gerações sob condições de laboratório, não observando a presença de machos. $\mathrm{O}$ autor trabalhou com diversas temperaturas, mantendo a umidade relativa em torno de $85 \%$, obtendo um período mínimo de incubação de 5 dias à $32^{\circ} \mathrm{C}$, com eclosão de apenas $47 \%$ das larvas. A $20^{\circ} \mathrm{C}$ o período médio de incubação foi de 15,4 dias, não ocorrendo a eclosão de larvas à $15^{\circ} \mathrm{C}$. A fase larval variou de 1 dia a 7 dias, sendo a fase quiescente de 1 dia a 5 dias, a fase de ninfa, incluindo os estádios de 
protoninfa e deutoninfa, variou de um dia e meio a 11 dias nas temperaturas de $32^{\circ} \mathrm{C}$ e $20^{\circ} \mathrm{C}$, respectivamente.

Haramoto (1969) estudou a biologia de B. phoenicis, em frutos de mamão, que foram cobertos com uma camada de parafina, o que diminuiu a sua superficie de transpiração, obtendo os seguintes periodos médios para as fases de ovo, larva, protoninfa, deutoninfa e ovo-adulto, sob umidade relativa de $65 \%-70 \%$, nas temperaturas de $20^{\circ} \mathrm{C}$ e $30^{\circ} \mathrm{C},: 22,2$ dias e 8,2 dias, 10,5 dias e 3,6 dias, 8,2 dias e 3,1 dias, 7,5 dias e 3,7 dias, 48,8 dias e 18,6 dias, respectivamente. A longevidade média de fềmeas adultas nestas condições de umidade foi de 45,8 dias e 10,5 dias.

Zaher et al. (1970) isolaram B. phoenicis em pequenos ramos de laranja com uma folha e um ou mais botões florais, obtendo 20,5 dias e 22,6 dias para o período de ovoadulto em temperaturas médias de $28,2^{\circ} \mathrm{C}$ e $25,9^{\circ} \mathrm{C}$ respectivamente. A $13,6^{\circ} \mathrm{C}$ este periodo alongou-se para 96,5 dias. Os autores obtiveram 10 gerações durante o ano, sendo que apenas três no outono e inverno. O número médio de ovos colocados por fềmea variou de 12,5 no inverno a 16,3 no verão.

Lal (1978) criou B. phoenicis em folhas de dois hospedeiros distintos, Clerodendron siphonanthus e Oroxylum indicum. As observações foram efetuadas diariamente, utilizando-se um microscópio estereoscópico. O autor fez descrições detalhadas de todos os estádios de desenvolvimento, efetuando medidas dos mesmos utilizando-se de uma lente ocular micrométrica previamente calibrada. $\mathrm{O}$ autor concluiu que a temperatura influenciou a duração do período dos diversos estádios, sendo o ciclo total (ovo-adulto) de 29,02 dias e 20,66 dias em $O$. indicum e 28,34 dias e 20,20 dias em C. siphonanthus nas temperaturas médias de $21,2^{\circ} \mathrm{C}$ e $26,6^{\circ} \mathrm{C}$ respectivamente, indicando que não ocorreu influência dos hospedeiros sobre o desenvolvimento do ácaro.

Chiavegato (1986) observou a biologia de B. phoenicis em frutos e folhas de laranja Pêra Rio, verificando que o periodo médio de incubação foi de 5,23 dias e 16,37 dias, sob temperaturas de $\left(20^{\circ} \mathrm{C}\right.$ e $\left.30^{\circ} \mathrm{C}\right) \pm 1^{\circ} \mathrm{C}$ respectivamente. O período ovo-adulto foi 
menor nos frutos quando comparado com as folhas, atingindo 14,37 dias contra 17,62 dias, sob temperatura de $30^{\circ} \mathrm{C}$. O autor afirmou que as folhas não constituem alimento conveniente para estes ácaros, principalmente quando são analisados o número de ovos por fềmea, que foi de 8,57 dias e 39,17 dias em folhas e frutos respectivamente. Nos frutos a duração média do ciclo vital foi de 48,8 dias , 19,2 dias e 14,4 dias, a longevidade 18,61 dias , 22,22 dias e 21,47 dias a $20^{\circ} \mathrm{C}, 25^{\circ} \mathrm{C}$ e $30^{\circ} \mathrm{C}$ respectivamente. $\mathrm{O}$ ciclo completo foi de 62,08 dias , 41,34 dias , 35,84 dias e o número de ovos 8,57, $22,52, \quad 39,17$ a $20^{\circ} \mathrm{C}, 25^{\circ} \mathrm{C}$ e $30^{\circ} \mathrm{C}$ respectivamente. $\mathrm{O}$ autor concluiu que os frutos cítricos são o melhor substrato para o desenvolvimento dos ácaros, ressaltando que a perda de ácaros durante a condução das observações afetaram os valores médios de alguns parâmetros analisados. $\mathrm{O}$ autor manteve a umidade relativa do ar em $60 \% \pm 10 \%$ e a fotofase de 14 horas.

Trindade \& Chiavegato (1994) observaram a biologia de B. phoenicis, Brevipalpus obovatus, Brevipalpus californicus, e obtiveram os seguintes períodos para a fase ovo-adulto : 29,9 dias $, 27,7$ dias e 26,5 dias na temperatura de $23^{\circ} \mathrm{C} \pm 1^{\circ} \mathrm{C}$ e 23,9 dias, 21,5 dias e 21,0 dias na temperatura de $27^{\circ} \mathrm{C} \pm 1^{\circ} \mathrm{C}$ respectivamente. Verificaram ainda que os períodos de incubação e as fases quiescentes foram as mais afetadas pela temperatura, não existindo diferenças quanto ao desenvolvimento das três espécies de ácaros.

Kennedy et al. (1996) determinaram a tabela de vida e de fecundidade de $B$. phoenicis, encontrando uma baixa taxa de crescimento $\left(\mathrm{r}_{\mathrm{m}}=0,127\right)$, mas uma alta taxa de sobrevivência e senescência. Foram verificados os seguintes parâmetros biológicos: taxa de reprodução de 33,2 ovos/fêmea, período ovo-adulto de 27,6 dias, dobrando a população a cada 5,5 dias. O hospedeiro utilizado foi a folha de chá (Camellia sinensis), colocadas em caixas de Petri, à temperatura de $26^{\circ} \mathrm{C} \pm 2^{\circ} \mathrm{C}$, umidade relativa de $65 \%-75 \%$ e fotofase de 16 horas. 
Nakano et al. (1987) determinaram a influência das lesões da verrugose nos frutos, provocadas pelo fungo Elsinoe fawcetti, sobre o comportamento de $B$. phoenicis em áreas de $5 \mathrm{~cm}^{2}$ delimitadas pela cola Tanglefoot ${ }^{\mathrm{R}}$. Nos frutos sem verrugose um maior número de ácaros se prenderam a cola na tentativa de alcançar local mais protegido. A quantidade de ácaros presos a cola foi elevada chegando a $54 \%$ e $82 \%$ nos frutos com e sem lesões respectivamente. Barreto \& Pavan (1995) confirmaram através da realização de ensaios e levantamentos, que quanto maior o índice de verrugose, menor foi a incidência da leprose, fato observado também por Albuquerque (1996), que verificou em laboratório, que frutos livres das lesões de verrugose estão mais sujeitos a apresentar as lesões de leprose, devido a maior movimentação de $B$. phoenicis em frutos lisos, o que torna o ácaro um vetor mais eficiente.

Teófilo Sobrinho et al. (1978) verificaram que o ácaro ocorre durante todo ano, sendo que $97 \%$ deles foram encontrados nos frutos e apenas $3 \%$ nas folhas. Prates (1984), verificou a maior incidência da leprose durante os meses de setembro e fevereiro, citando a ocorrência de $B$. phoenicis em mais de 80 gêneros. Em trabalhos de controle desenvolvidos no campo, Sudoi (1990) verificou que temperaturas não muito altas e ambiente relativamente seco favorecem a multiplicação de $B$. phoenicis, sendo que sua incidência variou ao longo do ano.

Chiavegato \& Mischan (1987) compararam o comportamento do ácaro da leprose em frutos de laranja Valência, tangor Murcote, limão Taiti, limão Siciliano e lima da Pérsia, e constataram um melhor desenvolvimento de $B$. phoenicis em laranja Valência e tangor Murcote, onde foi observado um maior número de ovos e forma ativas. Prates (1984) verificou que a variedade Valência, juntamente com Pêra, Natal e Hamlin apresentavam maior infestação de $B$. phoenicis, sendo portanto mais adequadas ao desenvolvimento do ácaro da leprose. Chiavegato \& Kharfan (1993) concluíram que os frutos constituem-se no local mais adequado para o desenvolvimento do ácaro da leprose, principalmente aqueles com lesões de verrugose, enquanto que as folhas se apresentaram como local menos apropriado. 
Oomen (1982) pesquisou a dinâmica da população de $B$. phoenicis, em plantas de chá, em condições de laboratório, concluindo que o ácaro apresentava baixa mobilidade. Os adultos iniciavam a migração, direcionada a locais com intensidades luminosas mais elevadas, sendo seguidos pelas formas mais jovens.

\subsection{Avaliação de danos e medidas de controle}

Chiavegato \& Salibe (1981) verificaram que a variedade Hamlim foi a que apresentou a menor incidência de ataque de $B$. phoenicis representada pelo menor número de frutos caídos ao chão, quando comparada com outras quatro variedades entre elas Itaboraí e Rubi que foram as mais afetadas pelo ácaro da leprose. Constataram ainda que $31 \%$ dos frutos colhidos nas plantas e $62 \%$ no solo apresentavam manchas de leprose, sendo que a maior parte dos frutos apresentavam cinco ou mais manchas a a perda média de peso foi de $5,66 \mathrm{~g}$ por fruto.

Chiavegato et al. (1982) realizaram a multiplicação do ácaro da leprose em frutos, e infestaram plantas sadias no campo, observando que a transmissão dos sintomas da leprose, ocorreram 36 dias após as infestações. Os autores constataram que frutos com

maior quantidade de ácaros apresentavam pesos menores quando comparados com a testemunha, ocorrendo uma perda média de 8,58 gramas, resultando em perdas diretas na sua comercialização.

Segundo Chiavegato (1987) pomares atacados pelo ácaro apresentam reduções drásticas na produção, as laranjas tem seu valor comercial reduzido, ocorrendo a queda prematura de folhas e frutos. $\mathrm{O}$ autor citou como fatores responsáveis pela situação da leprose no estado de São Paulo, as inspeções deficientes, as falhas no controle da verrugose e na aplicação de acaricidas, a superposição das safras de variedades tardias, poucos princípios ativos eficientes no controle da praga e diferenças na susceptibilidade do ácaro nas diversas regiões do estado. 
Violante Netto (1987) ressalta como possiveis causas da infestação do ácaro da leprose as pulverizações prematuras, ou tardias, intervalos longos entre as vistorias, ausência de vistoria nas partes internas, ocorrência no pomar de outras plantas hospedeiras do ácaro, tais como o capim amargoso e o picão preto e o uso indiscriminado de agrotóxicos, que em dosagens muito altas e até mesmo muito baixas podem causar o desequilibrio biológico.

Oliveira (1986) recomenda as seguintes medidas de controle em pomares com altas infestações do ácaro da leprose: a poda ou erradicação, aconselhada desde 1933 quando esta doença foi detectada pela primeira vez no Brasil, a eliminação de plantas hospedeiras do ácaro, evitar-se o plantio intercalar que pode abrigar o ácaro, antecipação da colheita, desinfecção do material de colheita incluindo veículos utilizados no transporte, evitando o trânsito dos mesmos de áreas contaminadas para áreas isentas do ácaro, controle da verrugose e finalmente a utilização de equipamento de pulverização adequado em condições ideais de uso. Oliveira (1995) observou que os acaricidas em muitas vezes oferecem um período de controle menor, devido a alta disseminação populacional do acarino e intensa migração de ácaros provenientes de outros pomares e de outras plantas hospedeiras. $\mathrm{O}$ autor recomenda a adoção de um sistema de monitoramento na cultura, como forma de reduzir o número de aplicações de defensivos agrícolas, sem perda de eficiência, qualidade e quantidade de produção, preservando o equilíbrio biológico do pomar.

Chiavegato et al. (1993) avaliaram o efeito do hexitiazox em combinação com diversos espalhantes adesivos, sobre fềmeas alimentadas em frutos tratados e suas progênies. O produto apresentou ação ovicida elevada, com eficiência superior a $70 \%$ em todos os tratamentos, não controlando eficientemente os adultos de $B$. phoenicis.

Gravena et al. (1994) observaram a atividade predatória de Euseius citrifolius sobre o ácaro da leprose dos citros sob condições de laboratório, mantendo a temperatura em $25 \pm 3^{\circ} \mathrm{C}$ e umidade relativa em $60 \pm 10 \%$. Foi montada uma arena sobre 
os frutos de laranja Valência, que circundada por tecido de algodão embebido de água, funcionava como barreira, impedindo a fuga dos ácaros. Os frutos foram colocados dentro de uma caneca plástica com água, que mantinha o tecido umedecido. A atividade predatória das larvas, ninfas e fềmeas adultas foi semelhante, sendo superior a dos machos adultos. A presença de lesões de verrugose nos frutos causou uma diminuição significativa na predação de $E$. citrifolius sobre $B$. phoenicis .

Mitidieri (1990) estudando o efeito de piretróides sobre o ácaro rajado, realizou a imersão de folhas de feijoeiro nas soluções inseticida por cinco segundos, que após o tratamento, receberam as fêmeas de Tetranychus urticae (Koch, 1836). Dennehy (1983) efetuando bioensaios de microimersão com $T$. urticae, não verificou diferenças significativas na mortalidade dos ácaros em períodos que variaram de 15 a 60 segundos.

Reis (1996) cita como vantagens da criação de ácaros em laboratório em relação à criação sobre plantas, em casa de vegetação ou telados, o maior controle sobre as espécies que estão sendo criadas, o pequeno espaço ocupado, além da economicidade deste método. O autor faz uma revisão dos métodos de criação de ácaros em laboratório, enquadrando-os em três categorias distintas, conforme o material utilizado como barreira: água como barreira, geralmente com a utilização de algodão embebido em água; uso de substâncias viscosas ou adesivas; e uso de espaços fechados, gaiolas ou células.

\subsection{Informações sobre o clorfenapir (Citrex 24 SC)}

\subsubsection{Descoberta e síntese}

Addor et al. (1992) trabalharam com Streptomyces e isolaram o dioxapirrolomicin, composto oriundo de fermentação, substância com moderada ação sobre insetos e ácaros, que apresentava uma potente ação desacopladora da fosforilação oxidativa. A descoberta desta substância, levou os pesquisadores ao novo grupo químico dos nitropirroles e pirroles halogenados. Em 1988, através da substituição de radicais na molécula de dioxapirrolomicin, foi sintetizado o clorfenapir, composto com largo 
espectro de ação inseticida-acaricida. A obtenção do dioxapirrolomicin, por meios sintéticos, permitiu a introdução de grupos aril, ciano, nitro, alkoximetil e trifluormetil no anel pirrole, o que abriu a perspectiva de desenvolvimento de novas classes de inseticidas e acaricidas, através de diferentes rotas de síntese (Kameswaran 1993, Hunt 1993). Farlow et al. (1991), conduziram ensaios de campo onde o clorfenapir obteve resultados de controle aceitáveis para uma série de pragas na cultura do algodão, entre elas o ácaro rajado (Tetranychus urticae).

\subsubsection{Propriedades físicas e químicas}

Nome químico :

4-bromo-2-(4-clorofenil)-1-(etoximetil)-5-(trifluorometil) pirrole-3-carbonitrila (IUPAC).

4-bromo-2-(4-clorofenil)-1-(etoximetil)-5-(trifluorometil)1H-pirrole-3-carbonitrila (CA).

Nome comum: clorfenapir

Grupo químico: pirroles

Fórmula molecular : $\mathrm{C}_{15} \mathrm{H}_{11} \mathrm{Br} \mathrm{ClF}_{3} \mathrm{~N}_{2} \mathrm{O}$.

Peso molecular : 407,6.

Aparência : sólido branco.

Odor: característico das cetonas.

Ponto de fusão : $100-101^{\circ} \mathrm{C}$.

Coeficiente de partição: KOW (octanol/ $/ \mathrm{H}_{2} \mathrm{O}$ ) : 67.670 em água destilada.

PH: 7,6 (dispersão aquosa a 1\%)

Pressão de vapor: $<1,3 \mu \mathrm{Pa}$ a $25^{\circ} \mathrm{C}$, essencialmente não volátil.

Solubilidade : solúvel em acetona, praticamente insolúvel em água.

Classe toxicológica III (Citrex 24 SC)

Formulação: Suspensão concentrada, contendo 240 gramas de clorfenapir por litro 


\subsubsection{Modo de ação}

O clorfenapir age por contato e principalmente por ingestão e apresenta ação translaminar, fator importante na estabilidade do produto na planta. O clorfenapir atua no processo respiratório dos insetos e ácaros, tendo a mitocôndria como principal sítio de ação, atuando como um desacoplador da fosforilação oxidativa. Essencialmente os pirroles rompem o gradiente eletroquímico de prótons da membrana mitocondrial e consequentemente impedem a conversão de $\mathrm{ADP}$ (difosfato de adenosina) em trifosfato de adenosina (ATP), fonte de energia das células, causando a sua morte e posterior morte dos insetos e ácaros (Treacy et al. 1994). Os autores trabalharam com larvas de Heliothis virescens e adultos de Leptinotarsa decemlineata em condições de laboratório e demonstraram que o clorfenapir também denominado AC 303,630, é um metabólito que necessita ser ativado via oxidação para exercer a sua função inseticida-acaricida. Ficou provado que o AC 303,628, um ácido fraco e lipofilico, é o composto oriundo dessa oxidação, realizada pela ação de enzimas (oxidases de função mista) presentes no interior das células dos ácaros e insetos, sendo o metabólito diretamente responsável pela ação inseticida-acaricida do clorfenapir. Como o $\mathrm{AC}$ 303,630 não é um ácido fraco, não é capaz de dissociar prótons e penetrar na membrana mitocondrial. O AC 303,628 é que desempenha esta função, atuando como um desagregador eletroquímico, desacoplando as reações da fosforilação oxidativa, impedindo a formação de ATP na mitocôndria, cessando as funções vitais das células, levando os insetos e ácaros à morte.

\subsubsection{Dados toxicológicos}

Tabela 1. Toxidade aguda do clorfenapir para mamiferos.

\begin{tabular}{ccc}
\hline Espécies & Técnico mg/kg & $\begin{array}{c}\text { Formulação } \\
24 \mathrm{SC} \mathrm{mg} / \mathrm{kg}\end{array}$ \\
\hline DL $_{50}$ oral rato (macho e fềmea) & 626 & 2973 \\
macho & 441 & 2102 \\
fềmea & 1152 & 3856 \\
DL $_{50}$ oral camundongo (macho e fềmea) & 55 & - \\
macho & 45 & - \\
fềmea & 78 & - \\
\hline
\end{tabular}

$\mathrm{SC}=$ Suspensão concentrada 


\section{MATERIAL E MÉTODOS}

Foram conduzidos três experimentos no Laboratório de Entomologia Econômica do Departamento de Entomologia da Escola Superior de Agricultura "Luiz de Queiroz", Piracicaba, São Paulo, no período de março a junho de 1996.

A temperatura foi mantida em torno de $26^{\circ} \mathrm{C} \pm 3^{\circ} \mathrm{C}$, utilizando-se quando necessário um aquecedor elétrico de três resistências. A umidade relativa, fator de importância na expressão do desenvolvimento dos sintomas da leprose, foi mantida em torno de $70 \% \pm 10$. Ambos os parâmetros foram registrados duas vezes ao dia, utilizando-se um termohigrômetro digital (Figura 1), que acusava também a temperatura e umidade máximas e mínimas do período. A fotofase foi de 14 horas, sendo controlada através de um "timer" ligado a rede elétrica da sala de criação. 


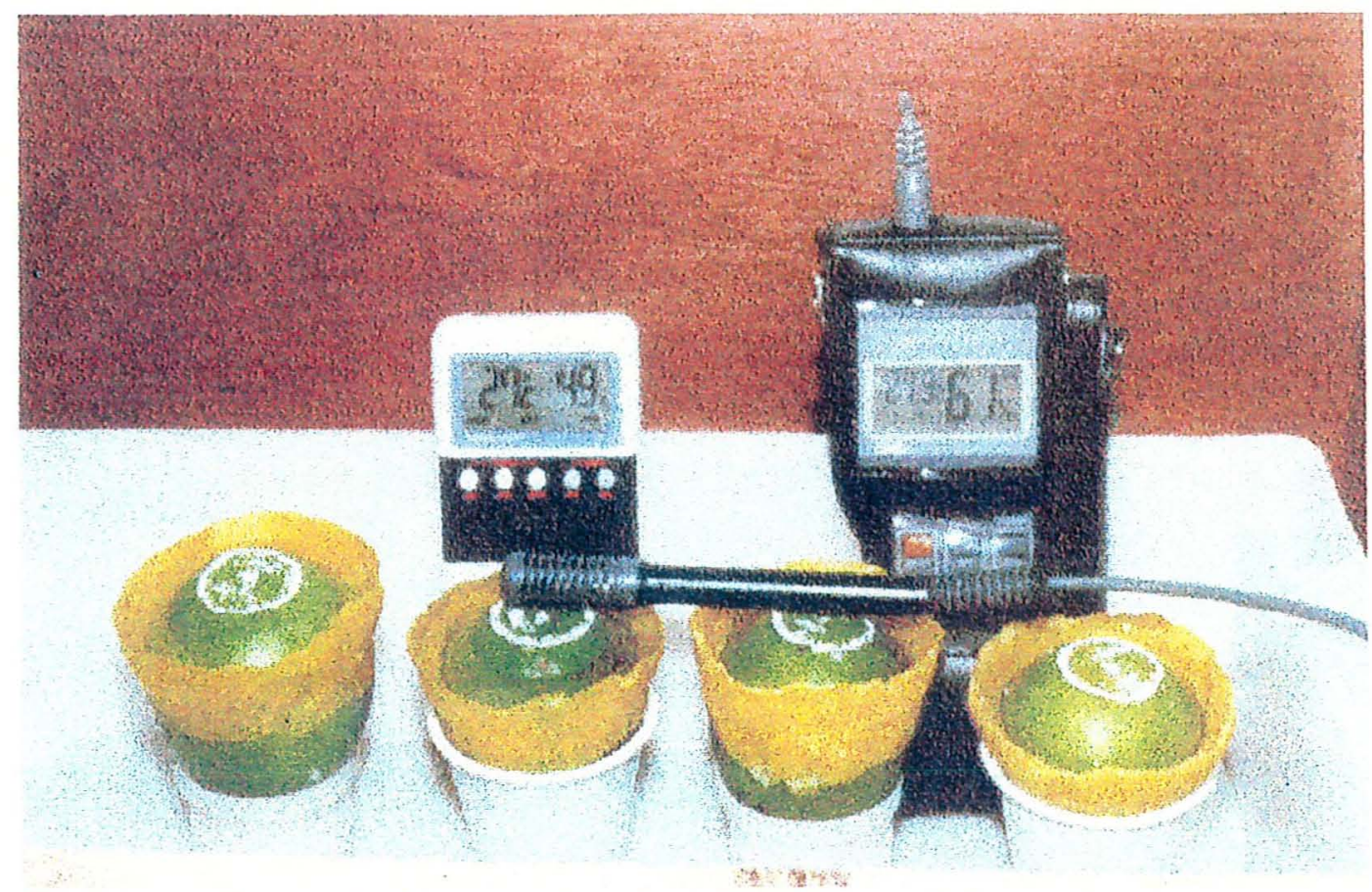

Figura 1 - Termohigrômetros digitais utilizados nas leituras de temperatura e umidade relativa.

\subsection{Coleta e manutenção de Brevipalpus phoenicis no laboratório}

A coleta dos ácaros foi realizada sempre num mesmo pomar, com alta infestação, apresentando os sintomas da leprose nos frutos e ramos, localizado no município de Araraquara, estado de São Paulo. Os frutos depois de colhidos foram acondicionados em caixas de isopor e transportados para o laboratório.

Os ácaros foram mantidos no laboratório em bandejas plásticas, à temperatura ambiente, nos frutos provenientes do campo, sendo retirados dos mesmos na medida em que os testes foram sendo instalados. Durante o período de condução dos testes foram efetuadas três coletas de ácaros no campo. 


\subsection{Procedimentos dos Bioensaios}

A variedade escolhida foi a Valência, pois o desenvolvimento de todas as formas ativas de Brevipalpus phoenicis é muito bom nessa laranja (Prates, 1984; Chiavegato \& Mischan, 1987).

Os frutos de laranjas utilizados foram coletados em um pomar que não apresentava sintomas da leprose e não tinha recebido qualquer tipo de pulverização nos últimos seis meses, evitando-se possiveis resíduos de produtos químicos que pudessem interferir na condução dos bioensaios. Os frutos verdes colhidos foram acondicionados em caixas de isopor e levados para o laboratório.

Os frutos, com diâmetro que variou de $54 \mathrm{~mm}$ a $70 \mathrm{~mm}$, em média $63 \mathrm{~mm}$, depois de lavados com água e sabão neutro e enxugados, foram preparados para receber o tratamento com os acaricidas e as fềmeas dos ácaros. Na região inferior do fruto, utilizando-se um gabarito, foi demarcada, com caneta esferográfica, uma área de aproximadamente $3 \mathrm{~cm}$ de diâmetro. Essa área passa a ser denominada a partir de agora de arena.

A arena foi recoberta com fita crepe e o fruto mergulhado na parafina líquida, com temperaturas que variaram de $70^{\circ} \mathrm{C}$ a $90^{\circ} \mathrm{C}$. A parafina proporcionou a proteção e impermeabilização do fruto. A área coberta pela fita crepe, depois da sua retirada, constituiu-se na arena propriamente dita onde as fềmeas dos ácaros foram colocadas e os bioensaios realizados. A parafina teve como função a conservação do fruto, diminuindo sua superficie de transpiração, dificultando a fuga do ácaro do interior da arena. Depois de efetuada esta operação a arena foi limpa com algodão embebido em álcool, eliminando-se qualquer resíduo de cola da fita crepe. Em seguida foram moldadas na superficie do fruto no interior da arena duas finas e tênues camadas da mistura de gesso mais areia na proporção de $1: 1$, misturada à água, ocupando por volta de $20 \%$ da área total da arena. Esta mesma mistura foi colocada na região de contato entre a parafina e o fruto. $\mathrm{Na}$ região média do fruto foi moldada, utilizando cera odontológica articulação 
para prótese de cor amarela, uma barreira capaz de armazenar a água e impedir a fuga dos ácaros da arena. A cera aderida à parafina que recobria o fruto, formou uma espécie de fosso, que sempre foi mantido cheio de água destilada. Esta água foi sendo reposta de acordo com sua evaporação, permanecendo constantemente um filme de água entre a cera e a parafina (Figura 2).

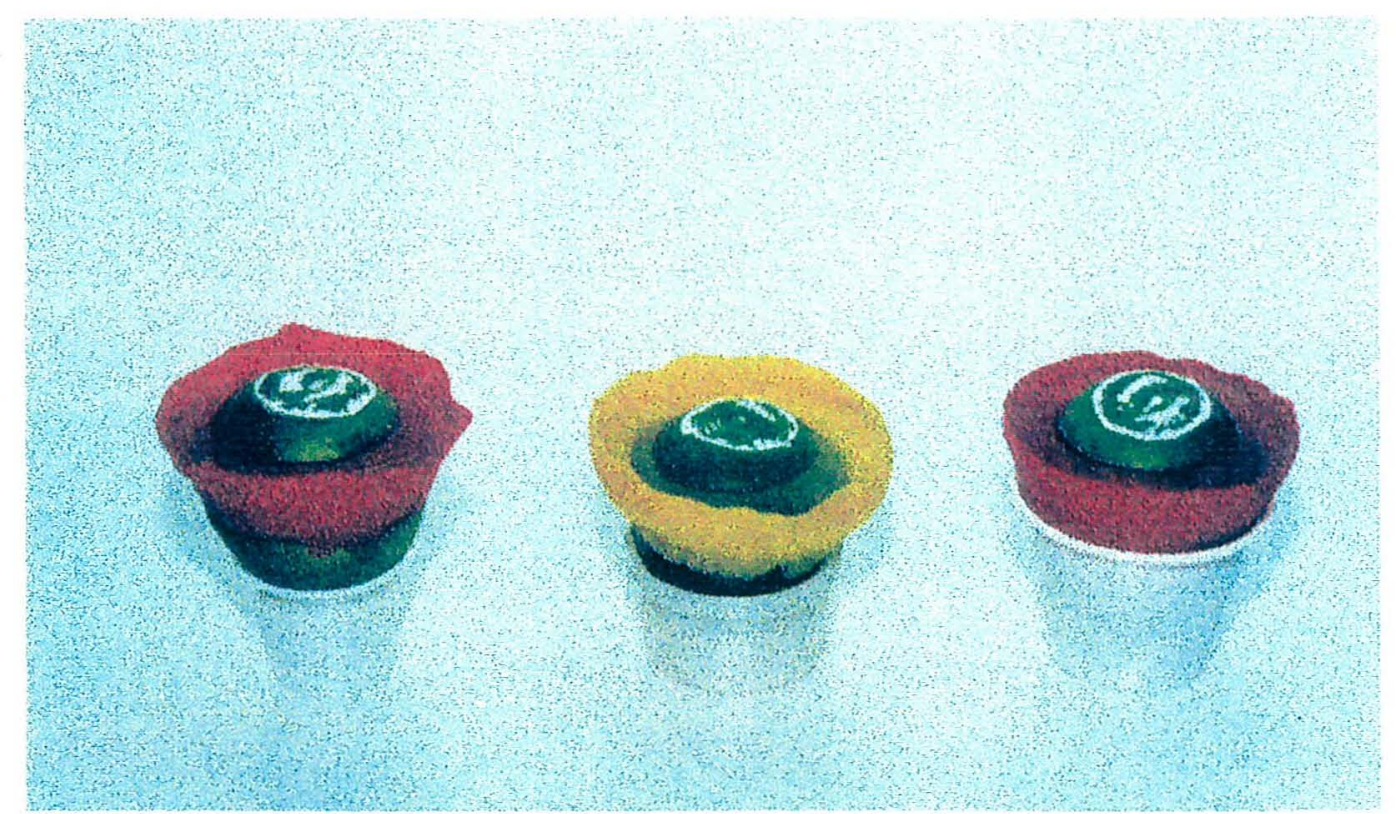

Figura 2 - Frutos preparados para receber as fêmeas adultas do ácaro da leprose, onde se notam as camadas de gesso e parafina, o nível da água, os tipos de suporte utilizados e duas cores de cera odontológica.

As fềmeas adultas foram transferidas dos frutos mantidos em laboratório para os frutos teste, utilizando-se um pincel de pelo de marta afilado em sua extremidade. Em cada fruto foram colocadas no interior da arena cinco fềmeas de idade desconhecida, com aspecto e comportamento semelhantes, baseando-se nas variações de coloração existentes entre as fềmeas do gênero Brevipalpus que tem a pigmentação preta aumentada de acordo com seu desenvolvimento e alimentação. 


\subsubsection{Bioensaio com aplicação do clorfenapir através do método de imersão}

Tabela 2. Tratamentos aplicados através do método de imersão.

\begin{tabular}{lcc}
\hline Tratamentos & $\begin{array}{c}\text { Concentração e formulação } \\
\text { do clorfenapir }\end{array}$ & $\begin{array}{c}\text { Dosagem do ingrediente } \\
\text { ativo }(\mathrm{g} \text { i.a. } / 100 \mathrm{~L}) .\end{array}$ \\
\hline 1. Testemunha & - & 0 \\
2. Clorfenapir & $24 \mathrm{SC}$ & 0,48 \\
3. Clorfenapir & $24 \mathrm{SC}$ & 0.77 \\
4. Clorfenapir & $24 \mathrm{SC}$ & 1,20 \\
5. Clorfenapir & $24 \mathrm{SC}$ & 1,92 \\
6. Clorfenapir & $24 \mathrm{SC}$ & 3,00 \\
\hline
\end{tabular}

As dosagens encontram-se em progressão logarítmica.

SC: Suspensão concentrada.

3.2.2 Bioensaio com aplicação através de imersão, com a mistura de gesso e areia tratada (GT) e não tratada (GNT) com o clorfenapir.

Tabela 3. Tratamentos aplicados através do método de imersão, com a mistura de gesso e areia tratada (GT) e não tratada (GNT) com o clorfenapir.

\begin{tabular}{lccc}
\hline Tratamentos & $\begin{array}{c}\text { Concentração e } \\
\text { Formulação do Citrex }\end{array}$ & $\begin{array}{c}\text { Dosagem do ingrediente } \\
\text { ativo (g i.a./100 L). }\end{array}$ & $\begin{array}{c}\text { Mistura } \\
\text { gesso+areia+água }\end{array}$ \\
\hline 1. Testemunha & - & 0 & GNT \\
2. Clorfenapir & $24 \mathrm{SC}$ & 1,20 & GNT \\
3. Clorfenapir & $24 \mathrm{SC}$ & 1,20 & GT \\
4. Clorfenapir & $24 \mathrm{SC}$ & 1,92 & GNT \\
5. Clorfenapir & $24 \mathrm{SC}$ & 1,92 & GT \\
\hline
\end{tabular}

GNT = mistura gesso e areia sem tratamento.

GT $=$ mistura gesso e areia tratada com clorfenapir 


\subsubsection{Bioensaio com pulverização dos acaricidas através da Torre de Potter}

Tabela 4. Tratamentos pulverizados através da Torre de Potter.

\begin{tabular}{lcc}
\hline Tratamentos & $\begin{array}{c}\text { Concentração e formulação } \\
\text { dos inseticidas }\end{array}$ & $\begin{array}{c}\text { Dosagem do ingrediente ativo } \\
\text { (g i.a. } / 100 \mathrm{~L})\end{array}$ \\
\hline 1. Clorfenapir & $24 \mathrm{SC}$ & 7,50 \\
2. Clorfenapir & $24 \mathrm{SC}$ & 1,92 \\
3. Clorfenapir & $24 \mathrm{SC}$ & 1,20 \\
4. Óxido de fenbutatin & $40 \mathrm{SC}$ & 20,00 \\
5. Testemunha & $24 \mathrm{SC}$ & 0 \\
\hline
\end{tabular}

\subsubsection{Forma de aplicação dos acaricidas}

A aplicação dos acaricidas foi realizada de duas maneiras distintas: pelo método da imersão, no primeiro e segundo bioensaios, e pela pulverização, utilizando-se a Torre de Potter, no terceiro bioensaio. No primeiro bioensaio, os frutos depois de preparados, ou seja, após terem recebido a mistura de gesso, mais areia e água, foram imersos nas soluções de diferentes concentrações contendo o clorfenapir.

No segundo bioensaio, a aplicação ocorreu de forma análoga ao primeiro, no entanto foi comparado o efeito desta aplicação na mistura gesso mais areia e água, que foi colocada nos frutos antes e depois da imersão dos frutos nas soluções contendo o clorfenapir. O tempo que cada fruto permaneceu imerso na solução acaricida nos dois bioensaios foi de dez segundos. As fềmeas adultas foram transferidas dos frutos mantidos em laboratório para os frutos teste, dois dias após estes terem recebido os tratamentos com o clorfenapir nos bioensaios de imersão.

No terceiro bioensaio, os frutos foram preparados de forma análoga ao primeiro bioensaio, e os ácaros foram transferidos para as arenas logo após a colocação da camada de gesso mais areia. A pulverização foi realizada quatro dias após a transferência das fềmeas para os frutos, ou seja, quando essas já haviam iniciado a postura. Nesse bioensaio a aplicação dos acaricidas foi realizada utilizando-se a Torre de Potter (Potter 
Precision Laboratory Spray Tower), calibrada para aplicar $150 \mathrm{l} / \mathrm{ha}$, com pressão de 5 $\mathrm{lb} / \mathrm{pol}^{2}$, a mesma utilizada por Komatsu (1988) em bioensaios de seletividade de Euseius concordis a acaricidas.

Nos três bioensaios, os frutos depois de preparados, tendo recebido os tratamentos acaricidas, foram colocados sobre suportes plásticos, mantidos com a arena voltada para cima, e acondicionados em bandejas plásticas, medindo $60 \mathrm{~cm} \times 30 \mathrm{~cm}$, dispondo-se 12 frutos, 15 frutos ou 18 frutos por bandeja. As bandejas plásticas foram colocadas no interior de caixas de madeira com tampa telada e mantidas no laboratório.

\subsection{Metodologia das avaliações}

Depois de realizada a aplicação dos acaricidas, foi avaliada a susceptibilidade do ácaro nas cinco fases de seu desenvolvimento: ovo, larva, protoninfa, deutoninfa e adulto, não distinguindo-se a protoninfa da deutoninfa, apesar das diferenças existentes entre esses estádios, tornando possivel a sua identificação (Hatzinikolis, 1986, Gonzales, 1975). Todas as observações e contagens das diversas formas ativas do ácaro foram realizadas com auxílio de um microscópio estereoscópio com ocular de 20 vezes de aumento. A contagem do número de fêmeas sobreviventes e das demais formas ativas dos ácaros foi realizada 2 dias, 5 dias, 7 dias, 10 dias, 14 dias, 20 dias, 21 dias e 22 dias após as infestações, dependendo do bioensaio em questão. Foram avaliadas a mortalidade de fêmeas, número de ovos, número de larvas, número de ninfas mortas e vivas e número de adultos da $1^{\mathrm{a}}$ geração.

\subsection{Análise estatística}

O delineamento experimental foi inteiramente aleatorizado. Nos três bioensaios foi efetuada a análise de variância e as médias foram comparadas duas a duas pelo do Teste t-Student, levando sempre em consideração o nível de significância de 5\%. Em todas as variáveis analisadas somou-se 0,5 aos valores originais, procedendo-se posteriormente as transformações necessárias as pressuposições da análise de variância. Em todas as Figuras os valores apresentados representam os valores originais obtidos. 


\section{RESULTADOS E DISCUSSÃo}

\subsection{Metodologia dos bioensaios}

A metodologia empregada utilizando a água como barreira, além de impedir a fuga dos ácaros, proporcionou um microclima mais estável na arena, mantendo a umidade relativa do ar e a temperatura constantes, o que favoreceu o desenvolvimento dos ácaros e a condução dos bioensaios. Este fato pode ser observado na Figura 1 onde a umidade relativa e temperatura na arena são de $61 \%$ e $27,9^{\circ} \mathrm{C}$, respectivamente, enquanto que na bandeja plástica, colocada dentro da caixa de madeira, que pode ser considerada como a condição ambiente elas são de $49 \%$ e $27^{\circ} \mathrm{C}$ respectivamente. Manglitz \& Cory (1953) determinaram a umidade relativa de $55 \%$ como a mais favorável ao desenvolvimento do ácaro Brevipalpus australis. Vários fatores interferem na dinâmica populacional e desenvolvimento de $B$. phoenicis, sendo considerados a temperatura e a umidade como os mais importantes (Chiavegato et al. 1982, Chiavegato 1986, Oliveira 1995, Lal 1978).

A mistura de gesso, areia e água proporcionou um local adequado de abrigo e postura para o ácaro (Figura 3), simulando na arena condição semelhante às lesões de verrugose no fruto, apresentando o inconveniente de impedir a contagem exata de todos os estádios de $B$. phoenicis, pois verificou-se que os ácaros eventualmente escondiam-se sob a camada de gesso mais areia, o que dificultava a sua visualização. A colocação da mistura de gesso mais areia na região de contato com o fruto evitou a formação a formação de espaços neste local, provocados pela perda de água dos frutos e descolamento da parafina. 
A cera de cor amarela substituiu com vantagens a de cor vermelha, utilizada nos testes preliminares, facilitando a localização dos ácaros, devido ao maior contraste entre a cor de B. phoenicis e da cera.

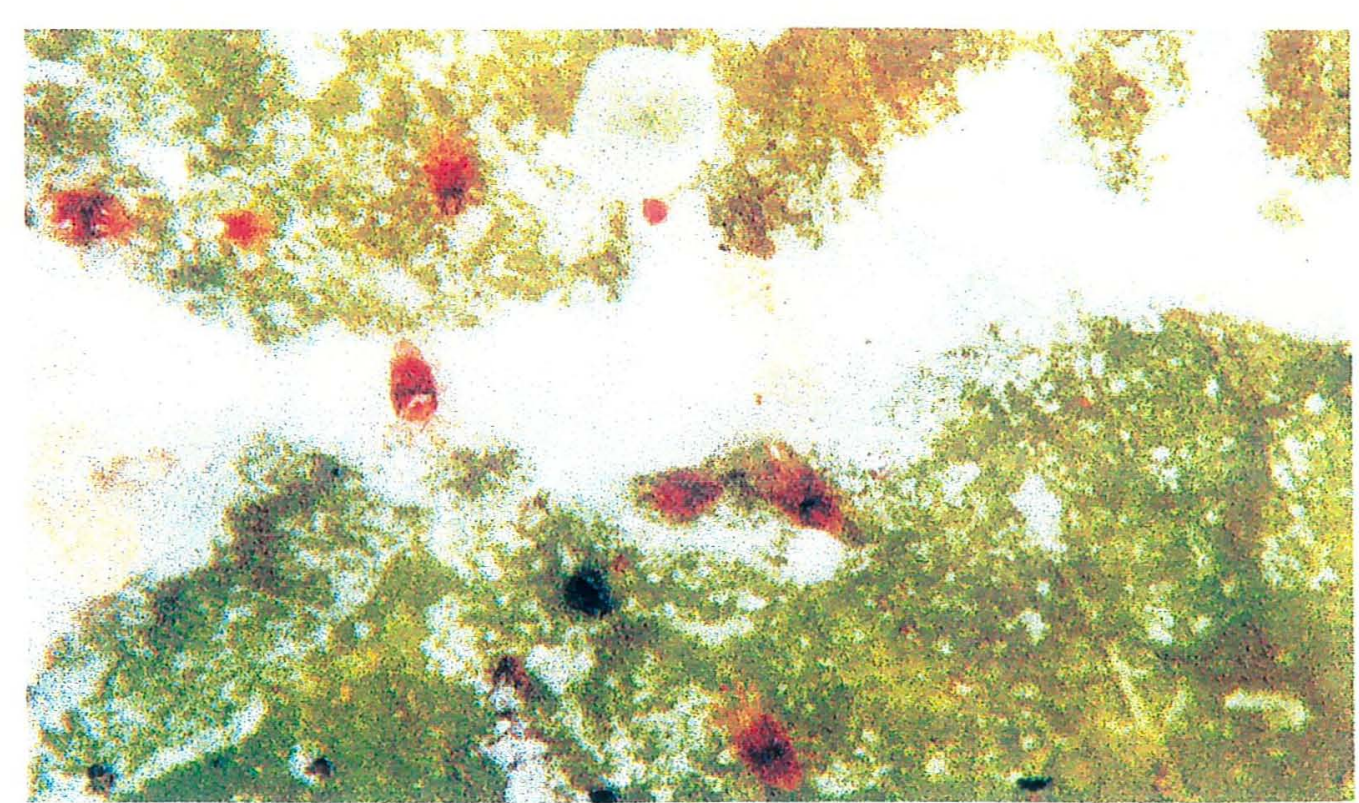

Figura 3 - Detalhe do fruto preparado com o gesso e areia, onde observam-se as fềmeas adultas, larvas, ninfas e ovos de Brevipalpus phoenicis.

As dosagens dos acaricidas, nos três bioensaios, foram baseadas nos resultados obtidos nos testes preliminares. As concentrações sub-letais do clorfenapir proporcionaram a sobrevivência de parte da população inicial de fêmeas e consequentemente a condução dos bioensaios.

\subsection{Comportamento da fêmea na postura}

Foi constatado que a fêmea após o término da postura, procura ao redor do ovo grânulos de areia, gesso, poeira ou até mesmo detritos para proteger o ovo recém colocado, sendo cronometrado por cinco vezes, durante a condução dos bioensaios, este tempo que variou de 12 a 16 minutos, sendo na média de 15 minutos, praticamente o mesmo tempo gasto na postura em si. Zaher (1970), constatou que a fềmea deposita os ovos individualmente em botões florais, e em áreas côncavas dos frutos, cobrindo os 
ovos com pequenos resíduos para protegê-los. O mesmo autor observou ainda que a oviposição leva de 12 a 30 minutos nas estações quentes do ano.

Verificou-se que a fềmea procura locais abrigados, como depressões no gesso, exúvias do ácaro ou fendas existentes entre a parafina e o gesso para realizar a postura. Resultados semelhantes foram observados por Chiavegato (1986) e Haramoto (1969), que constataram a presença de ovos em fendas nas folhas e nos frutos, em escamas de cochonilhas, envolvidos nas próprias exúvias, em grânulos de poeira e na axila de um broto. Os ovos apesar de terem sido encontrados agrupados em determinados frutos em sua maioria foram ovipositados isoladamente não sendo observada a tendência de agregação descrita por Chiavegato (1986).

\subsection{Bioensaio com aplicação do clorfenapir através do método de imersão}

\subsubsection{Mortalidade de fêmeas (\%)}

A análise da variância mostrou que o efeito dos dias e das diferentes dosagens, sobre a mortalidade de fềmeas, foram significativos ao nível de $5 \%$, e que a interação destas duas variáveis também mostrou significância, permitindo concluir que o número de fêmeas mortas é crescente de acordo com o aumento da dosagem e tempo decorrido entre a infestação e a data de avaliação. 


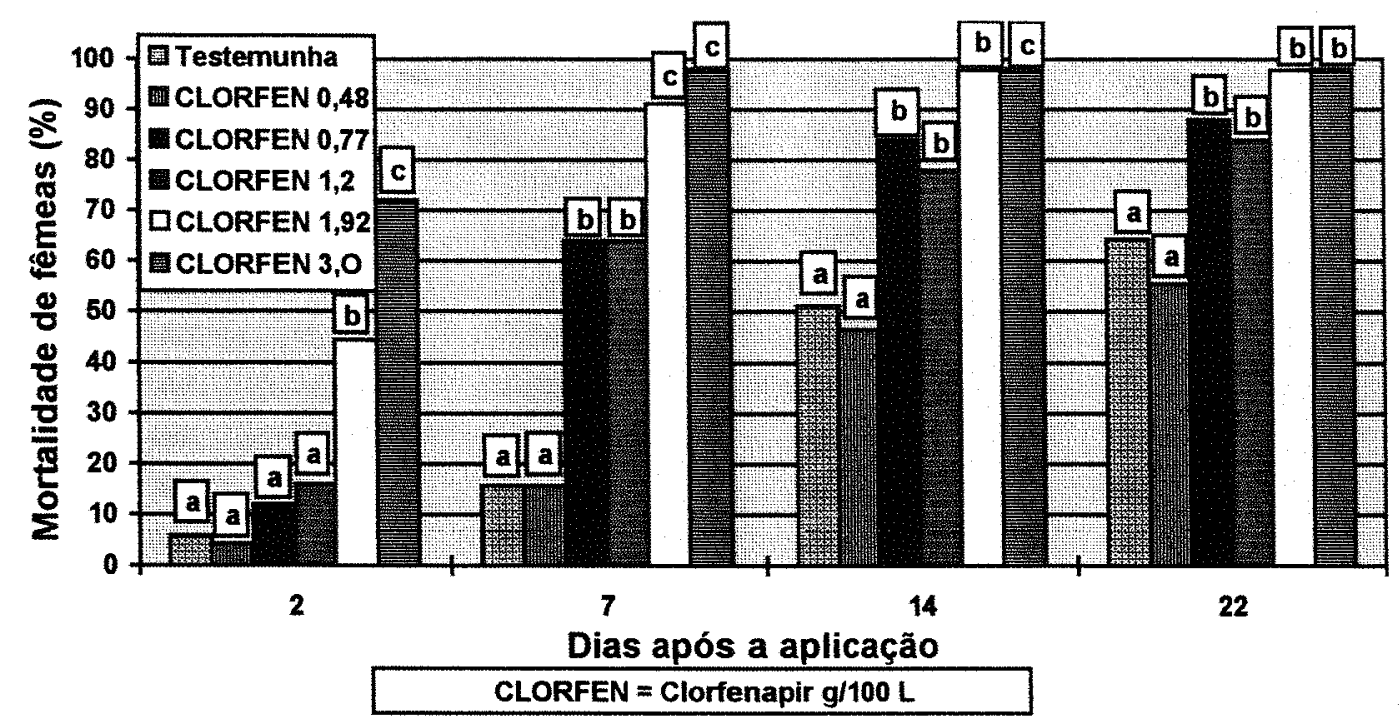

Figura 4 - Mortalidade de fêmeas (\%), bioensaio de imersão. Dados acompanhados pela mesma letra não diferem estatisticamente ao nível de $5 \%$. As comparações entre os tratamentos foram realizadas em uma mesma data.

A Figura 4 mostra que aos 2 DAI (dias após a infestação), apenas as dosagens mais altas, 1,92 g i.a./100 L e 3,0 g i.a./100 L, diferiram estatisticamente da testemunha e dos demais tratamentos. Com o passar do tempo as doses sub-letais de $0,77 \mathrm{~g}$ i.a. $/ 100 \mathrm{~L}$, $1,2 \mathrm{~g}$ i.a./100 L aumentaram a sua eficiência no controle das fêmeas, alcançando mortalidade superior a $80 \%$ aos 22 DAI, não diferindo estatisticamente das dosagens mais altas. A dosagem de $0,48 \mathrm{~g}$ i.a. $/ 100 \mathrm{~L}$ ao longo de todo o teste não foi eficiente no controle de fêmeas, obtendo niveis de mortalidade semelhantes à testemunha, não diferindo estatisticamente ao nível de $5 \%$.

Deve-se ressaltar que com o passar do tempo a mortalidade de fêmeas na testemunha também foi crescente superando a observada na dosagem de $0,48 \mathrm{~g}$ i.a./100 L nas leituras de 14 DAI ( $51 \%$ contra $47 \%$ ) e 22 DAI ( $64 \%$ contra $56 \%$ ). A mortalidade manteve-se baixa na testemunha e na dosagem de $0,48 \mathrm{~g}$ i.a./100 L até os $7 \mathrm{DAI}(15,5 \%$ para ambos tratamentos), o que demonstrou a eficiência da barreira de água, mantendo os ácaros no interior da arena. A partir desta leitura os índices de moralidade foram crescentes o que pode ser explicado pela idade da fêmeas. Para evitar este tipo de problema as fềmeas utilizadas no teste teriam que ser jovens, e de idade conhecida. 


\subsubsection{Número de ovos}

Como o número de fêmeas diminuiu de acordo com o aumento da dosagem, o número de ovos acompanhou esta tendência, pois este parâmetro está diretamente relacionado ao número de fềmeas sobreviventes. $\mathrm{O}$ número de ovos colocados pelas fêmeas sofreu uma interferência direta da dosagem do clorfenapir e do tempo, sendo que as fềmeas que sobreviveram não tiveram a sua postura afetada pela ação do acaricida. A análise da variância mostrou que existiram diferenças significativas entre as dosagens testadas e o tempo, ocorrendo também uma interação significativa entre esses dois parâmetros.

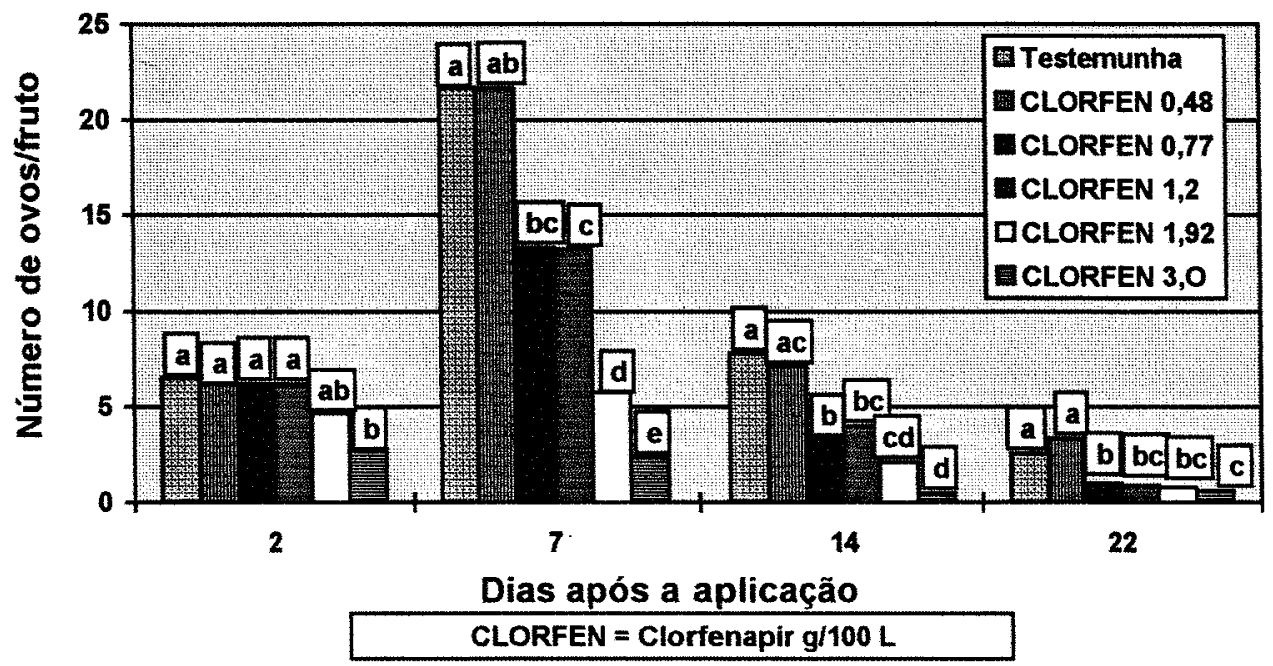

Figura 5: Número médio de ovos, bioensaio de imersão. Dados acompanhados da mesma letra não diferem estatisticamente ao nivel de 5\%. As comparações entre os tratamentos foram realizadas em uma mesma data.

Observa-se que mesmo na testemunha, a postura decresceu a partir dos 14 dias após a infestação, sendo que isso se deveu a dois fatores: mortalidade e idade das fềmeas.

Como as dosagens de $1,92 \mathrm{~g}$ i.a./100 L e 3,0 g i.a./100 L apresentaram um efeito de choque maior, obtendo mortalidade de fềmeas superior a 90\% já aos 7 DAI, a diminuição do número de ovos foi mais acentuada nestes dois tratamentos. 


\subsubsection{Número de larvas vivas}

A análise da variância mostrou que para esse parâmetro ocorreram diferenças significativas entre as dosagens e o tempo, existindo também uma interação significativa entre esse dois fatores.

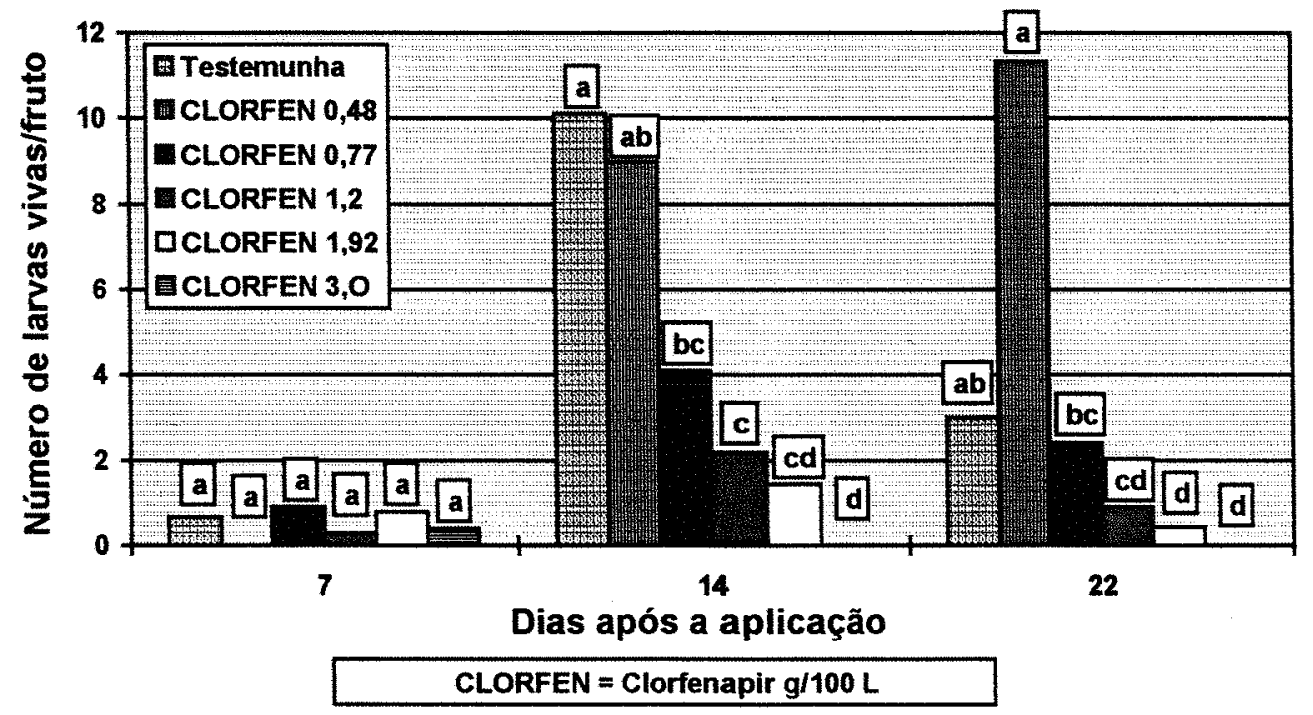

Figura 6: Número médio de larvas vivas, bioensaio de imersão. Dados acompanhados da mesma letra não diferem estatisticamente ao nível de $5 \%$. As comparações entre os tratamentos foram realizadas em uma mesma data.

Ocorreu uma tendência de diminuição do número de larvas vivas, conforme se aumentou a dosagem do clorfenapir, excetuando-se a dosagem de $0,48 \mathrm{~g}$ i.a. $/ 100 \mathrm{~L}$ aos $22 \mathrm{DAI}$, onde o número de larvas vivas foi superior ao da testemunha, o que não pode ser explicado, mas demonstrou a baixa eficiência do produto nessa dosagem. Na dosagem de $3,0 \mathrm{~g}$ i.a./100 L apenas aos $7 \mathrm{DAI}$ existiam larvas vivas $(0,4$ larvas/fruto), sendo que aos $14 \mathrm{DAI}$ e $22 \mathrm{DAI}$ o controle foi de praticamente 100\%. Essa dosagem foi considerada muito eficiente no controle de larvas.

\subsubsection{Número de ninfas vivas}

A análise da variância demonstrou que existiram diferenças significativas entre as dosagens testadas aos 14 e 22 após a infestação, mas na interação desses dias com as dosagens elas não ocorreram. 


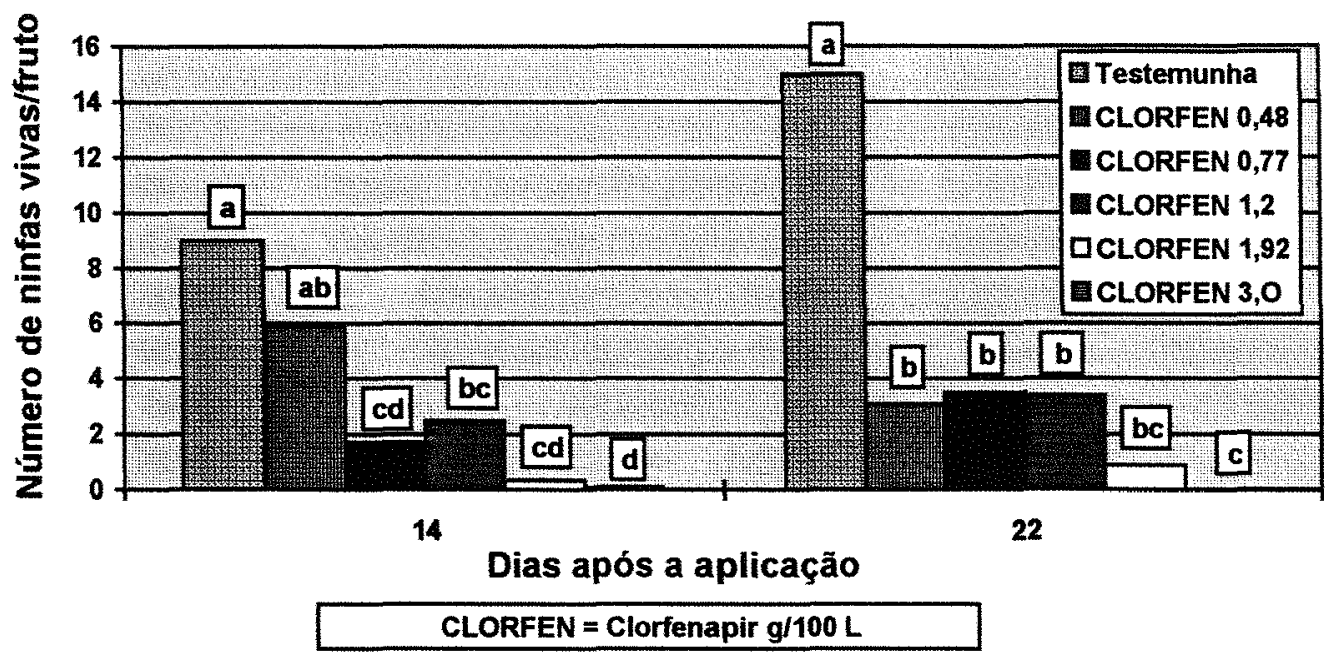

Figura 7: Número médio de ninfas vivas, bioensaio de imersão. Dados acompanhados da mesma letra não diferem estatisticamente ao nível de $5 \%$. As comparações entre os tratamentos foram realizadas em uma mesma data.

De uma maneira geral nas dosagens mais baixas é que ocorreram os maiores números de ninfas vivas, ficando evidente que a análise desse parâmetro é importante quando se comparam as diferentes dosagens do clorfenapir. Novamente a dosagem de 3,0 $\mathrm{g}$ i.a. $/ 100 \mathrm{~L}$ proporcionou um controle de ninfas de praticamente $100 \%$ aos $14 \mathrm{DAI} \mathrm{e}$ $100 \%$ aos 22 DAI.

\subsection{Bioensaio com aplicação através da imersão, com a mistura de gesso e areia tratada (GT) e não tratada (GNT) com o clorfenapir}

Verificou-se nesse bioensaio a diferença entre realizar a imersão do fruto na solução com o clorfenapir antes e depois da colocação da mistura gesso mais areia no fruto, pois os ácaros permanecem muito tempo neste local.

Os resultados demonstraram que inicialmente a eficiência do controle foi maior nos frutos que receberam a mistura de gesso e areia mais clorfenapir. No entanto, com o decorrer do tempo, nos tratamentos sem clorfenapir no gesso e areia, a mortalidade das fêmeas e os demais parâmetros observados foram igualando-se aos observados nos tratamentos que receberam o acaricida na mistura gesso mais areia. 


\subsubsection{Mortalidade de fềmeas (\%)}

A análise da variância mostrou que existem diferenças significativas na mortalidade das fềmeas ao nível de $5 \%$ quando se analisam isoladamente as dosagens e a influência do gesso tratado e não tratado com o clorfenapir. No entanto isso não ocorre quando se analisa a interação desses parâmetros, ou a combinação deles com os dias decorridos após a infestação.

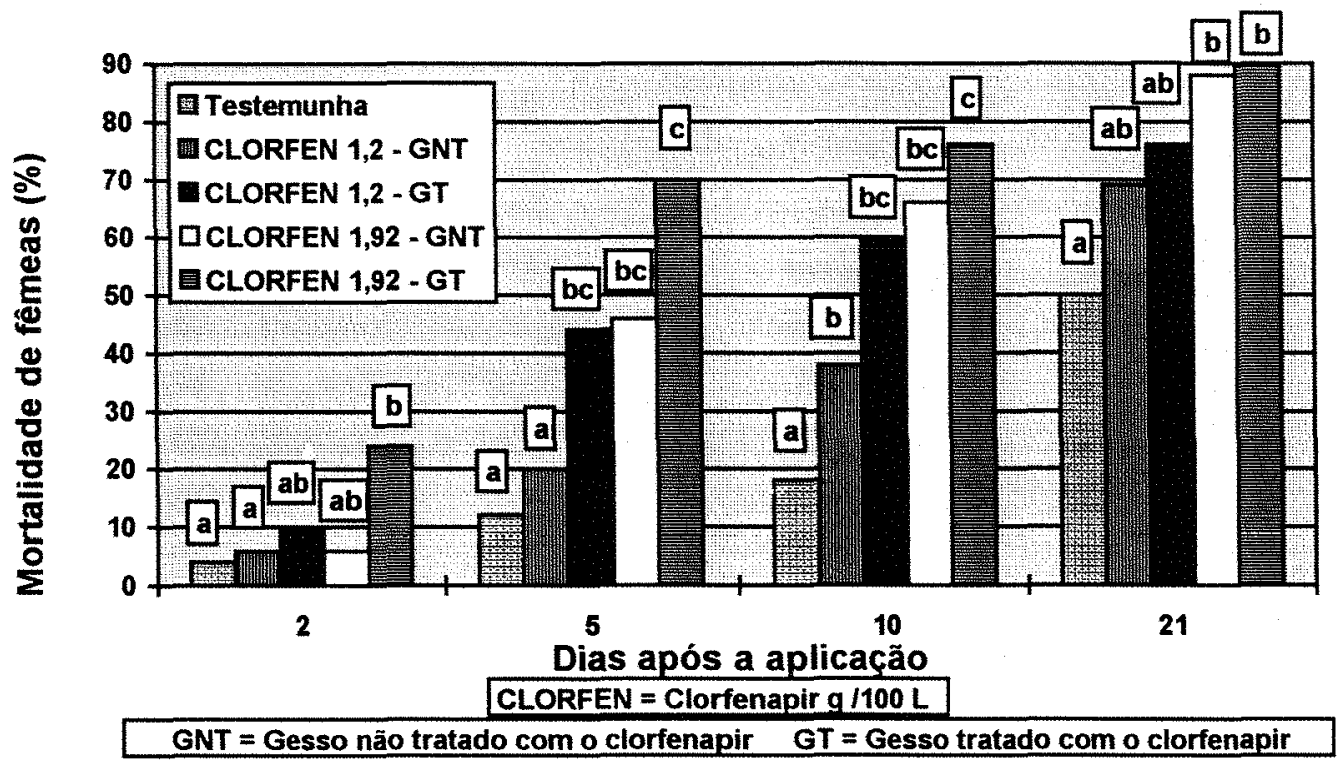

Figura 8 - Mortalidade de fềmeas (\%), bioensaio de imersão com gesso tratado e não tratado com o clorfenapir. Dados acompanhados da mesma letra não diferem estatisticamente ao nível de 5\%. As comparações entre os tratamentos foram realizadas em uma mesma data.

Em todos os tratamentos ocorreu uma mortalidade crescente das fêmeas, com o passar do tempo, inclusive na testemunha. A comparação entre os tratamentos onde o gesso não recebeu o tratamento com o clorfenapir (GNT), com o gesso tratado com o acaricida (GT), mostrou que apesar de existir uma tendência da mortalidade ser maior nos tratamentos com o gesso tratado nos primeiros dias após a aplicação, apenas aos 5 DAI, na dosagem de 1,2 g i.a./100 L, ocorreu diferença estatística entre estas duas formas de aplicação, ao nível de 5\%. Esse fato ocorreu, provavelmente, porque os ácaros permaneceram mais tempo na camada de gesso e areia, entrando em contato com o clorfenapir e intoxicando-se mais rapidamente. 


\subsubsection{Número de ovos}

A análise da variância mostrou que existiram diferenças estatísticas entre os diversos tratamentos, quando foi analisada a interação do efeito das dosagens ao longo dos dias. Esses dois parâmetros quando analisados individualmente também apresentaram diferenças significativas, mas a presença do gesso tratado (GT) e não tratado (GNT) com o clorfenapir, não interferiu na postura das fềmeas.

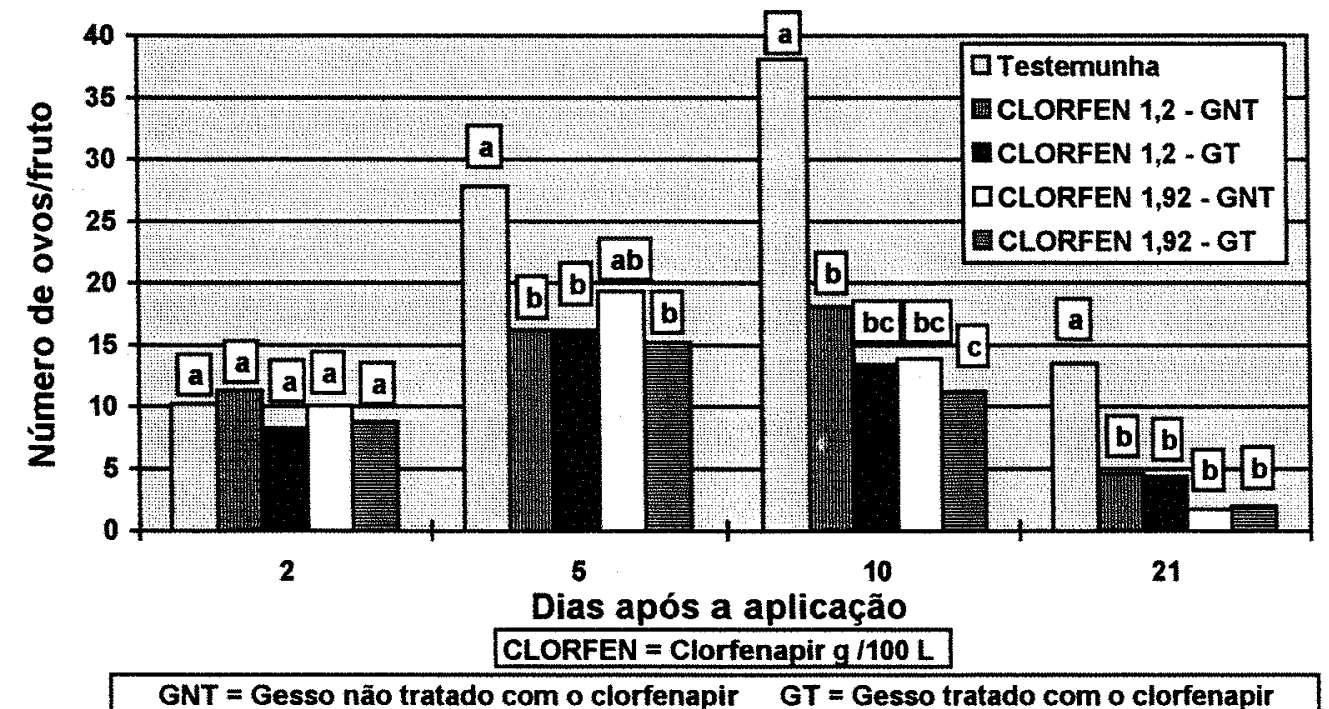

Figura 9 - Número médio de ovos, bioensaio de imersão com gesso tratado e não tratado com o clorfenapir. Dados acompanhados da mesma letra não diferem estatisticamente ao nível de 5\%. As comparações entre os tratamentos foram realizadas em uma mesma data.

A análise da Figura 9 mostra que entre os tratamentos onde o gesso não foi tratado (GNT) e tratado (GT) com o clorfenapir, não existiram diferenças significativas ao nível de $5 \%$. A diferença no número de ovos também não ocorreu entre as dosagens de $1,20 \mathrm{~g}$ i.a./100 L e 1,92 g i.a./100 L de clorfenapir.

\subsubsection{Número de larvas mortas}

A análise da variância mostrou que o desempenho do clorfernapir foi muito semelhante para esse parâmetro, ao que já havia ocorrido com a postura. Ocorreram as mesmas interações entre os dias e as dosagens e a comparação do gesso tratado e não 
tratado com o inseticida apresentou diferenças significativas ao nível de $5 \%$ apenas aos 10 dias na dosagem de $1,2 \mathrm{~g}$ clorfenapir/100 L.

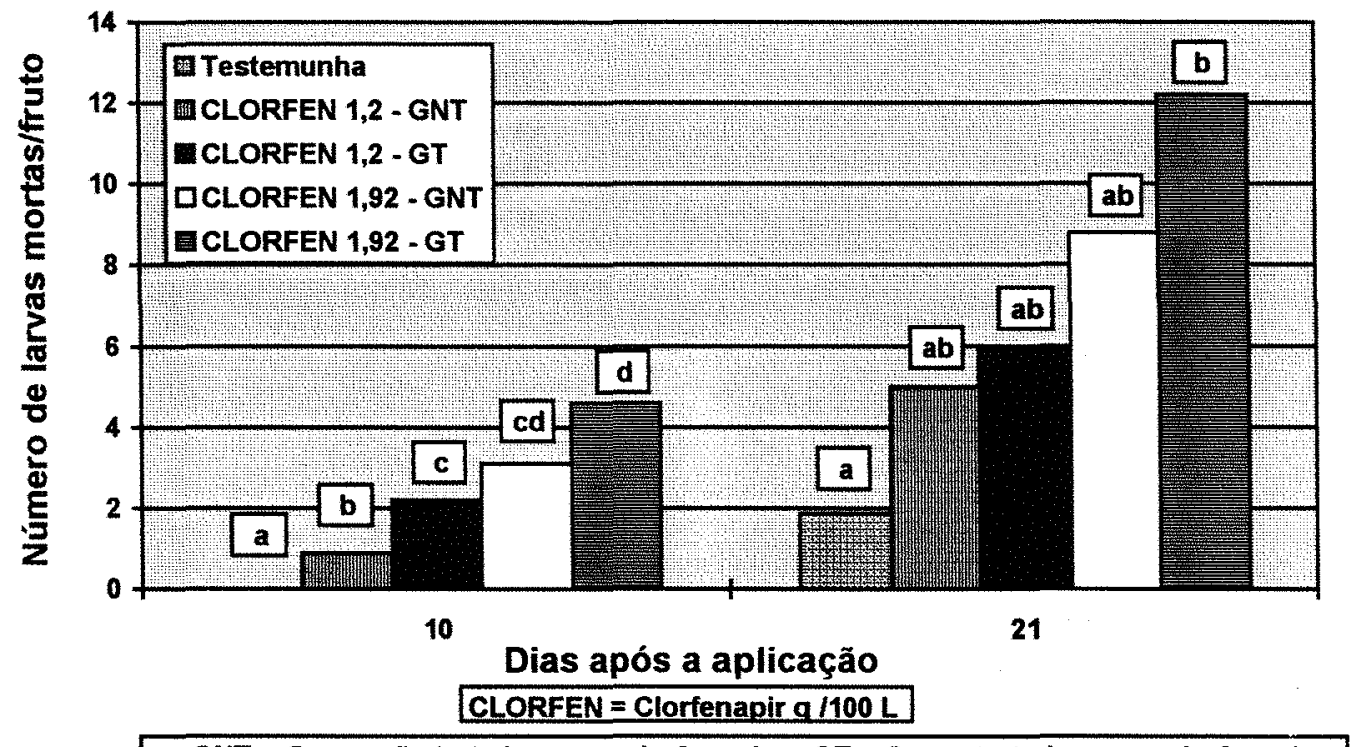

GNT = Gesso näo tratado com o clorfenapir GT = Gesso tratado com o clorfenapir

Figura 10 - Número médio de larvas mortas, bioensaio de imersão com gesso tratado e não tratado com o clorfenapir. Dados acompanhados da mesma letra não diferem estatisticamente ao nivel de $5 \%$. As comparações entre os tratamentos foram realizadas em uma mesma data.

Apesar do número médio de larvas mortas ter sido maior nos frutos onde o gesso recebeu o tratamento com o clorfenapir (GT), o que pode ser explicado pela preferência dessa forma do ácaro em se abrigar nesse local, e portanto permanecer mais tempo em contato com o produto, apenas na avaliação de $10 \mathrm{DAI}$, na dosagem de 1,20 i.a./100 L é que existiu diferença estatística entre as duas formas de aplicação (GT e GNT).

\subsubsection{Número de larvas vivas}

A análise de variância mostra que, o desempenho dos tratamentos foi muito semelhante para esse parâmetro, sendo o número de larvas vivas foi decrescente conforme se aumentou a dosagem do clorfenapir. Este fato já havia ocorrido com o número de ovos e número de larvas mortas. Apesar de existir uma interação entre os dias e as dosagens, quando foram comparados os tratamentos com gesso tratado (GT) e não 
tratado com o clofernapir (GNT), apenas aos 21 DAI na dosagem de $1,92 \mathrm{~g}$ i.a./100 L ocorreu diferença estatística entre estas duas formas de aplicação do acaricida.

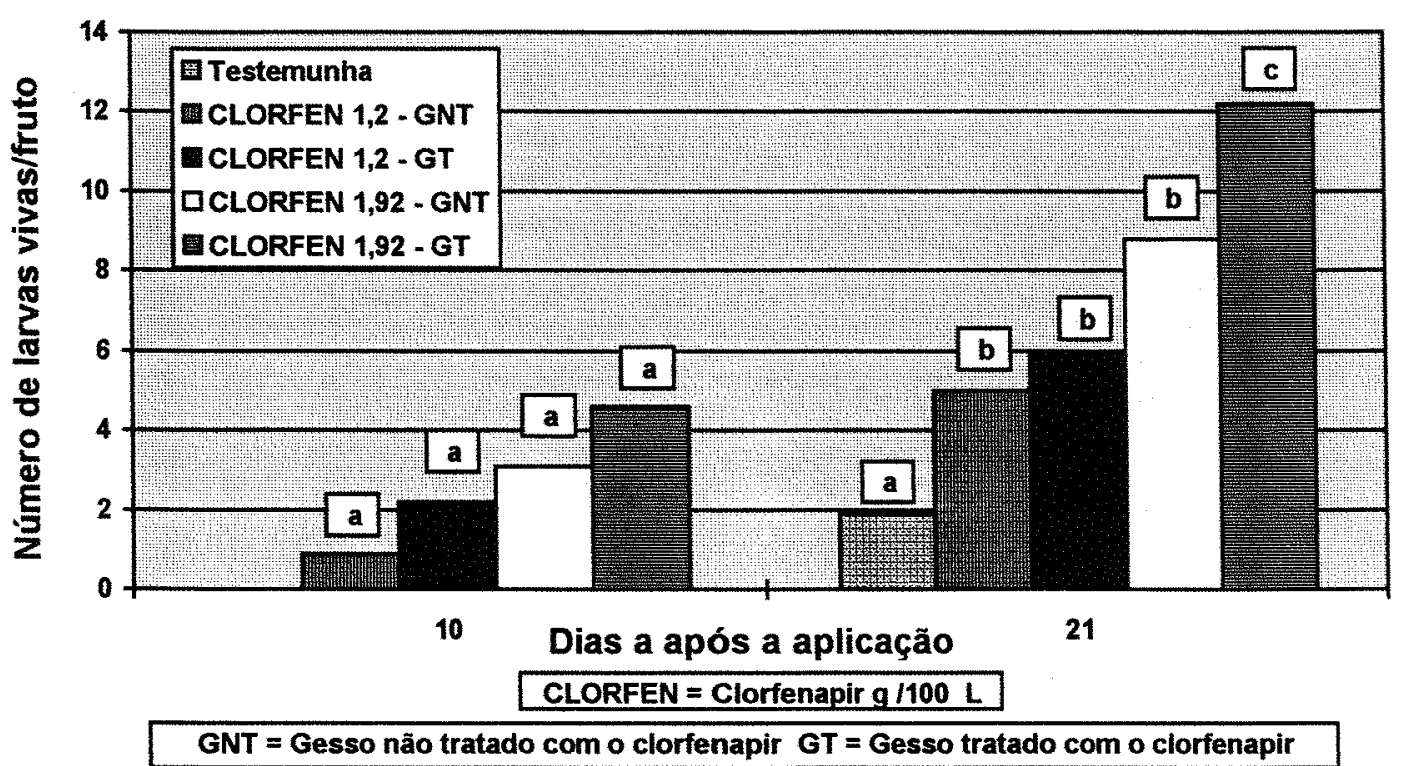

Figura 11 - Número médio de larvas vivas, bioensaio de imersão com gesso tratado e não tratado com o clorfenapir. Dados acompanhados da mesma letra não diferem estatisticamente ao nível de $5 \%$. As comparações entre os tratamentos foram realizadas em uma mesma data. 


\subsubsection{Número de ninfas vivas}

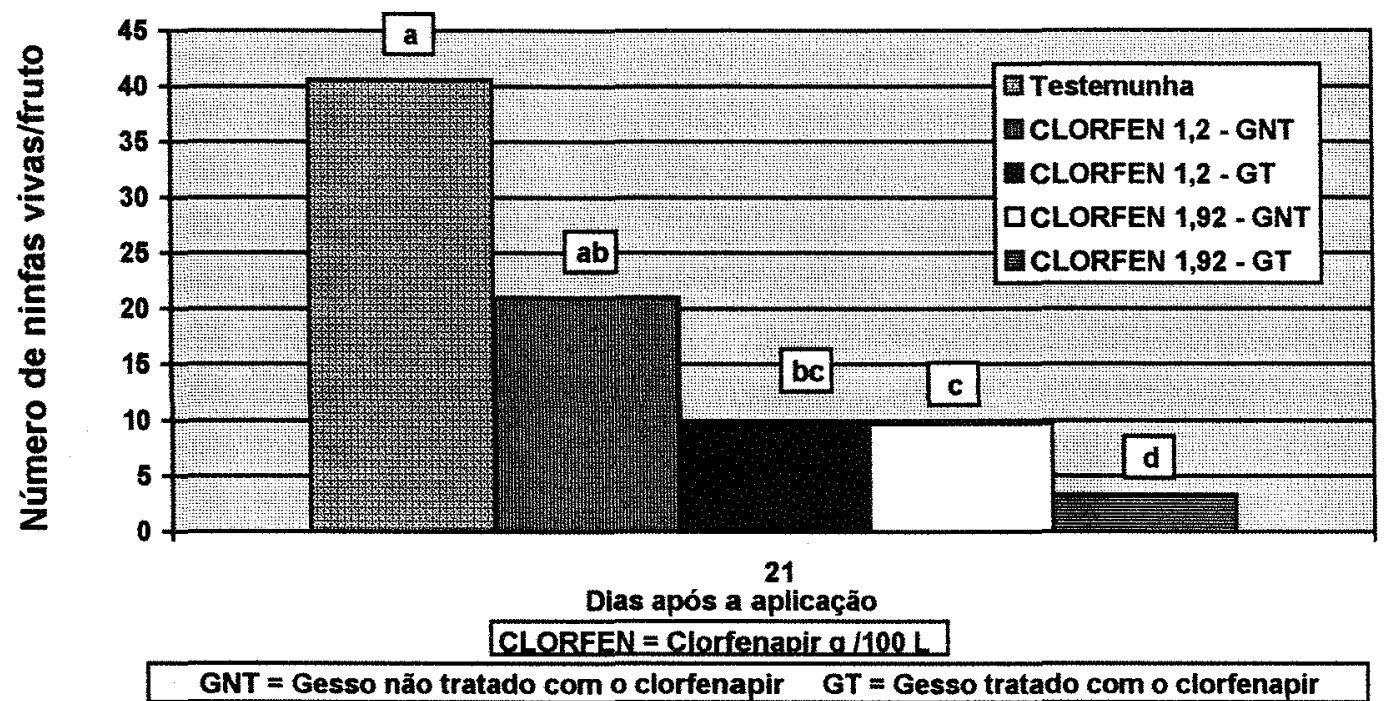

Figura 12 - Número médio de ninfas vivas, bioensaio de imersão com gesso tratado e não tratado com o clorfenapir. Dados acompanhados da mesma letra não diferem estatisticamente ao nivel de $5 \%$. As comparações entre os tratamentos foram realizadas em uma mesma data.

Existiu uma tendência da diminuição do número de ninfas vivas, diretamente proporcional ao aumento na dosagem do clorfenapir, sendo comprovado estatisticamente ao nivel de probabilidade de $5 \%$. A Figura 12 mostra que apesar de existir um número menor de ninfas vivas nos tratamentos com gesso tratado com clorfernapir (GT), do que nos tratamentos sem tratamento do gesso (GNT), apenas na dosagem de $1,92 \mathrm{~g}$ de clorfenapir $/ 100 \mathrm{~L}$, ocorreu diferença estatística ao nível de probabilidade de $5 \%$.

\subsubsection{Número de adultos de $1^{\mathrm{a}}$ geração}

Para este parâmetro não foi possível realizar a análise de variância, devido a heterogeneidade dos dados, sendo apresentado apenas os dados originais obtidos da contagem do número de adultos (Figura 13). 


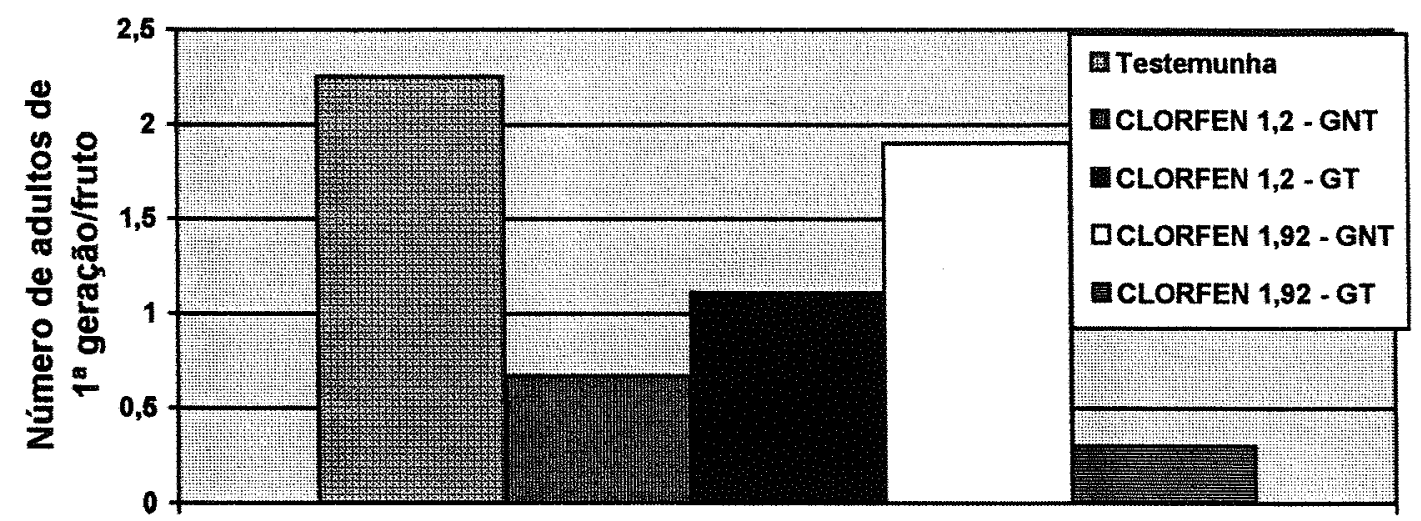

21

Dias após a aplicação

CLORFEN $=$ Clorfenapir $\mathrm{g} / 100 \mathrm{~L}$

GNT = Gesso não tratado com o clorfenapir $\quad$ GT = Gesso tratado com o clorfenapir

Figura 13 - Número médio de adultos da $1^{\text {a }}$ geração, bioensaio de imersão com gesso tratado e não tratado com o clorfenapir. Dados acompanhados da mesma letra não diferem estatisticamente ao nível de $5 \%$. As comparações entre os tratamentos foram realizadas em uma mesma data.

Apesar do maior número de adultos observado na testemunha, a análise individual desse parâmetro, não apresenta diferenças numéricas entre os tratamentos com gesso tratado e não tratado com o clorfenapir que possam ser interpretadas estatisticamente. $O$ número de adultos da primeira geração na dosagem de $1,92 \mathrm{~g}$ i.a. $/ 100 \mathrm{~L}$, foi superior ao encontrado na dosagem de $1,20 \mathrm{~g}$ i.a./100 L, fato que não pode ser explicado. Deve-se considerar que assim que apareceram os primeiros adultos o ensaio foi encerrado.

\subsection{Bioensaio com pulverização dos acaricidas através da Torre de Potter}

\subsubsection{Mortalidade de fêmeas (\%)}

Ocorreram diferenças significativas entre as dosagens ao longo do tempo. Houve também uma interação significativa entre essas duas variáveis. 


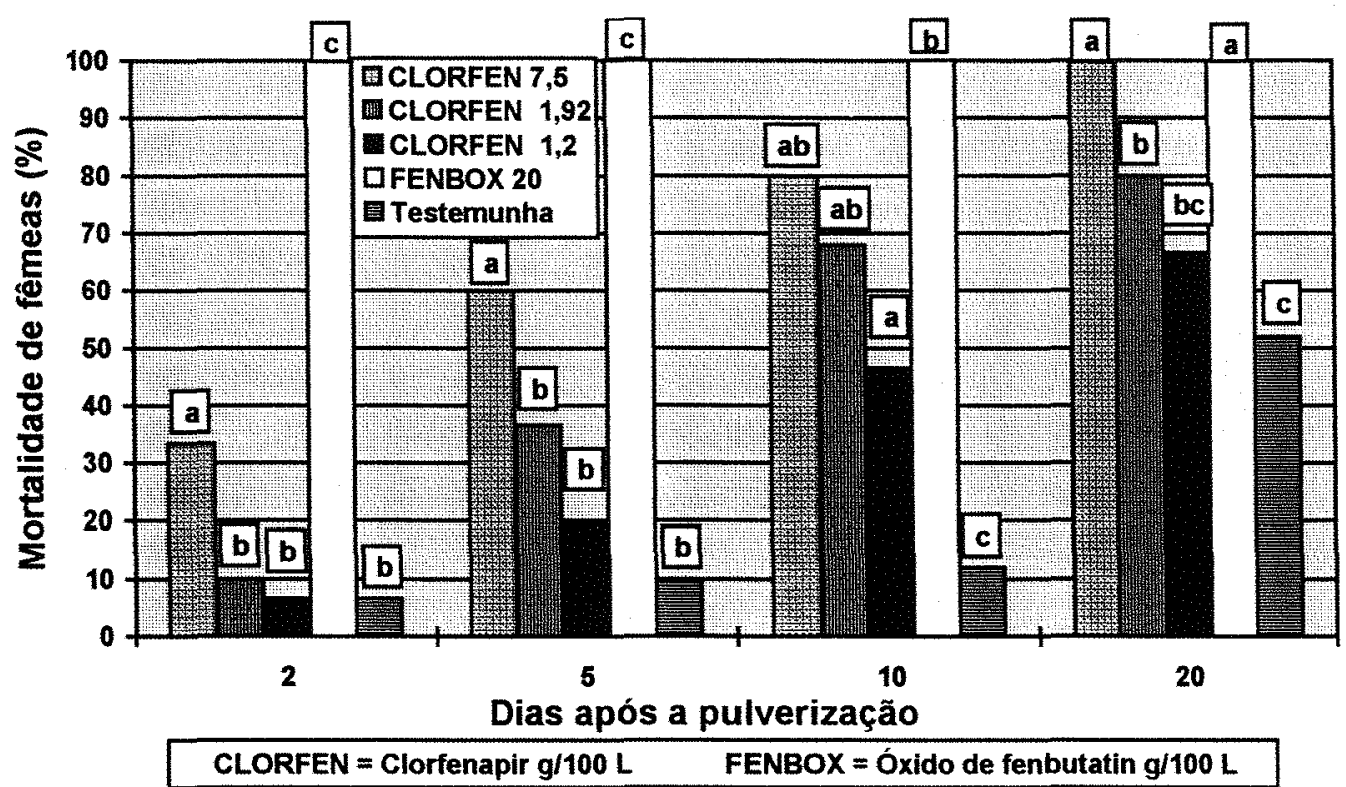

Figura 14 - Mortalidade de fềmeas (\%), bioensaio com pulverização através da Torre de Potter. Dados acompanhados da mesma letra não diferem estatisticamente ao nivel de $5 \%$. As comparações entre os tratamentos foram realizadas em uma mesma data.

O efeito do óxido de fenbutatin verificado nos testes preliminares foi confirmado, ficando clara a rápida ação desse acaricida que aos 2 dois dias após a pulverização (DAT) já alcançou $100 \%$ de mortalidade das fêmeas, resultado comparável aos obtidos por Vendramini et al. (1993), que observaram a eficiência do óxido de fenbutatin no campo a partir de cinco dias, agindo no entanto, mais rapidamente do que os demais produtos testados. O desempenho do óxido de fenbutatin foi superior e estatisticamente diferente de todos os demais tratamentos ao nível de probabilidade de 5\%, exceto quando comparado com o clorfenapir na dosagem de 7,5 g i.a./100 L aos $20 \mathrm{DAT}$, que apesar de ter alcançado $100 \%$ de mortalidade das fềmeas apresentou uma ação mais lenta. Esse fato apresenta implicações importantes na aplicação desses resultados para o campo, tendo em vista a importância da ação de choque dos acaricidas no controle do ácaro da leprose. Essa ação mais lenta do clorfenapir pode explicar o comportamento semelhante do produto nas três dosagens utilizadas, ocorrendo diferenças estatísticas nas seguintes situações: dosagem de 7,5 g i.a. $/ 100 \mathrm{~L}$ comparada com as dosagens de $1,92 \mathrm{~g}$ i.a./100 L e 1,2 g i.a. $/ 100 \mathrm{~L}$ aos 2 dias, 5 dias e 20 dias após o tratamento. 


\subsubsection{Número de ovos.}

Apesar das fêmeas adultas terem permanecido por quatro dias nos frutos, antes dos mesmos terem recebido a pulverização dos acaricidas, portanto esses apresentavam um número variado de ovos, existiram diferenças estatísticas entre os tratamentos quando foi analisado a influência das dosagens e dos dias isoladamente, não ocorrendo no entanto uma interação entre essas duas variáveis.

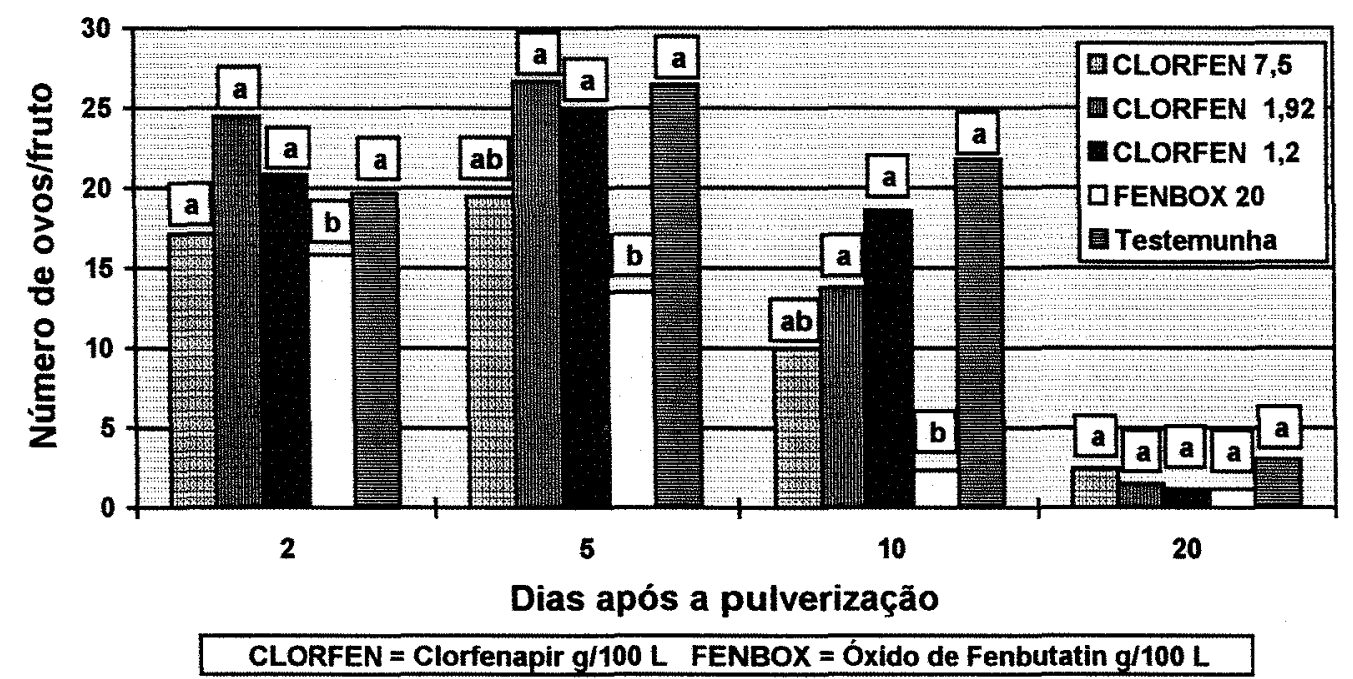

Figura 15: Número médio de ovos, bioensaio com pulverização através da Torre de Potter. Dados acompanhados da mesma letra não diferem estatisticamente ao nível de $5 \%$. As comparações entre os tratamentos foram realizadas em uma mesma data.

Devido ao número inicial de ovos antes da pulverização ser semelhante em todos os tratamentos, as diferenças estatísticas entre as dosagens de clorfenapir ocorreram a partir da avaliação de 2 DAT, sendo que nesta data o óxido de fenbutatin foi estatisticamente diferente de todos os demais tratamentos. Aos 5 DAT e 10 DAT o óxido de fenbutatin não diferiu estatisticamente apenas da dosagem de 7,5 g de clorfenapir/100 L, obtendo os melhores resultados. Não ocorreram diferenças estatísticas significativas entre as três dosagens de clorfenapir ao longo do tempo, apesar de numericamente o número de ovos ser superior nas dosagens menores. Este fato ocorreu devido ao elevado número de ovos existentes no frutos na data da aplicação dos acaricidas, em média 14,2 ovos/fruto (13,6 ovos/fruto na dosagem de $7,5 \mathrm{~g}$ de clorfenapir/100 L; 15,2 ovos/fruto na 
dosagem de $1,92 \mathrm{~g}$ de clorfenapir/100 L; 14,3 ovos/fruto na dosagem de $1,2 \mathrm{~g}$ de clorfenapir/100 L e 14 ovos/fruto nos tratamentos de óxido de fenbutatin e testemunha). Aos 20 DAT todos os tratamentos foram iguais estatisticamente, isto ocorreu pois o número de ovos era muito baixo em todos os tratamentos.

\subsubsection{Número de larvas mortas}

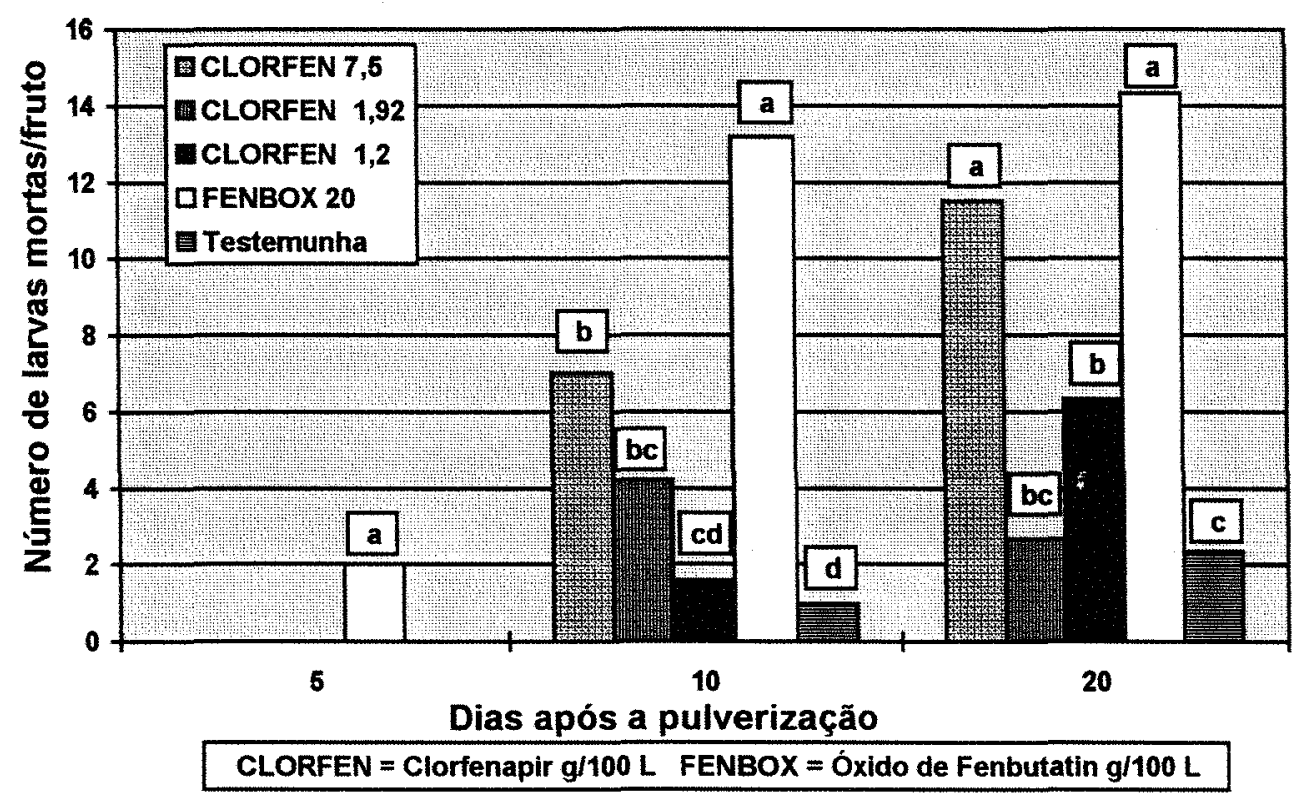

Figura 16 - Número médio de larvas mortas, bioensaio com pulverização através da Torre de Potter. Dados acompanhados da mesma letra não diferem estatisticamente ao nível de $5 \%$. As comparações entre os tratamentos foram realizadas em uma mesma data.

Novamente o efeito mais rápido do óxido de fenbutatin ficou evidente na análise desse parâmetro, sendo que as primeiras larvas mortas apareceram aos 5 DAT. Apenas a dosagem de 7,5 g i.a./100 L de clorfenapir aos 20 DAT não diferiu estatisticamente do produto considerado padrão (óxido de fenbutatin) neste bioensaio. A dosagem de 7,5 $\mathrm{g}$ i.a./100 L aos $10 \mathrm{DAT}$, foi à testemunha e a dosagem de $1,2 \mathrm{~g}$ de clorfenapir/100 L, não diferindo estatisticamente da dosagem de $1,92 \mathrm{~g}$ i.a./100 L. 


\subsubsection{Número acumulado de larvas mortas}

$\mathrm{Na}$ Figura 17 as diferenças entre os tratamentos podem ser visualisadas de uma maneira clara, onde observa-se que a dosagem de $1,2 \mathrm{~g}$ i.a./100 $\mathrm{L}$ obteve um maior número acumulado de larvas mortas do que a dosagem de $1,92 \mathrm{~g}$ i.a./100 L, o que ocorreu provavelmente devido a menor mortalidade de fêmeas (Figura 14) e maior número de ovos (Figura 15) neste tratamento.

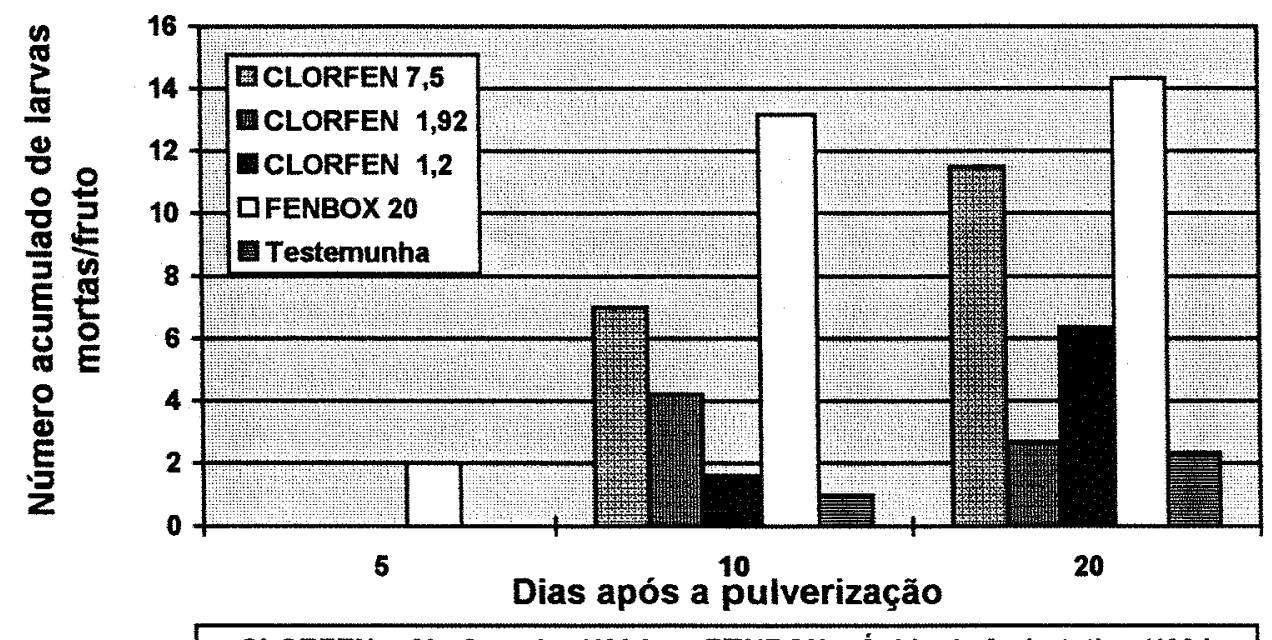

CLORFEN $=$ Clorfenapir g/100 L FENBOX $=$ Óxido de fenbutatin g/100 L

Figura 17 - Número médio acumulado de larvas mortas, bioensaio com pulverização através da Torre de Potter. Dados acompanhados da mesma letra não diferem estatisticamente ao nivel de $5 \%$. As comparações entre os tratamentos foram realizadas em uma mesma data. 


\subsubsection{Número de larvas vivas}

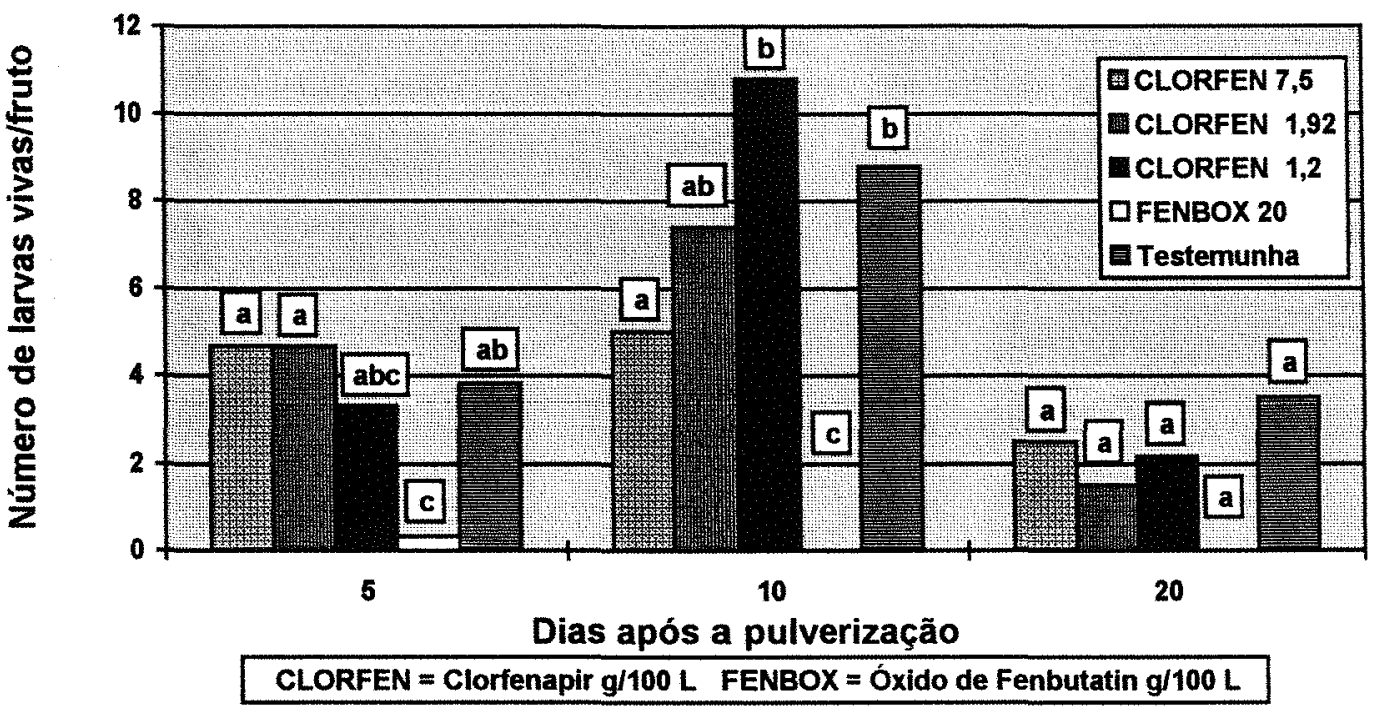

Figura 18 - Número médio de larvas vivas, bioensaio com pulverização através da Torre de Potter. Dados acompanhados da mesma letra não diferem estatisticamente ao nível de $5 \%$. As comparações entre os tratamentos foram realizadas em uma mesma data.

Nessa variável as diferenças entre os tratamentos não foram marcantes e apenas o óxido de fenbutatin diferiu estatisticamente dos demais tratamentos aos 5 DAT e 10 DAT, e apesar de não existirem larvas vivas no tratamento com óxido de fenbutatin aos 20 DAT, como nos demais tratamentos o número delas foi pequeno, todos os tratamentos não diferiram estatisticamente nessa data. 


\subsubsection{Número de ninfas vivas}

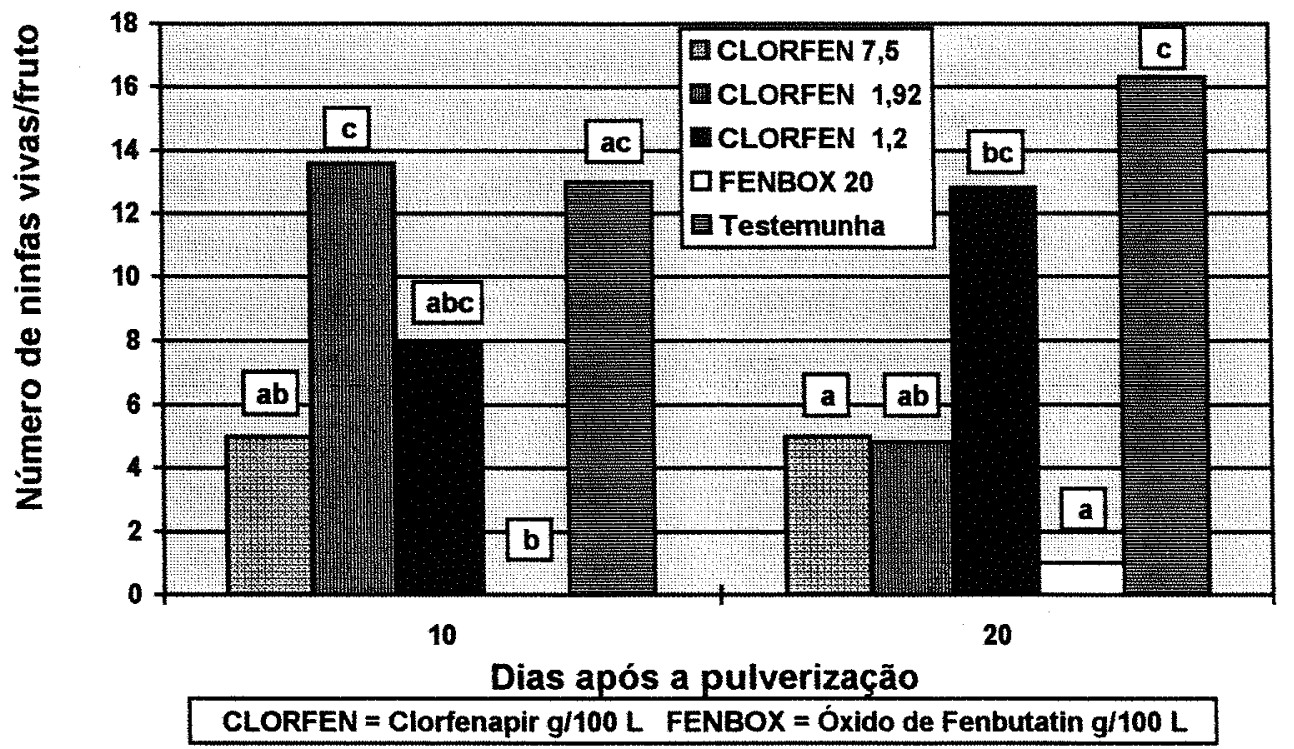

Figura 19 - Número médio de ninfas vivas, bioensaio com pulverização através da Torre de Potter. Dados acompanhados da mesma letra não diferem estatisticamente ao nível de $5 \%$. As comparações entre os tratamentos foram realizadas em uma mesma data.

A análise dessa variável complementa a efetuada para o parâmetro ninfas mortas, e nesse caso o desempenho do óxido de fenbutatin foi o melhor. Mesmo não existindo ninfas vivas aos 10 DAT na dosagem de $20 \mathrm{~g}$ de óxido de fenbutatin/100 L, ele não diferiu estatisticamente das dosagens de 7,5 g e 1,2 g de clorfenapir/100 L. Aos 20 DAT o óxido de fenbutatin diferiu estatisticamente apenas da testemunha e da dosagem de 1,2 $\mathrm{g}$ de clorfenapir/100 L. As dosagens de $1,2 \mathrm{~g}$ e $1,92 \mathrm{~g}$ de clorfenapir/100 L não apresentaram diferenças estatísticas tanto aos 10 DAT quanto aos 20 DAT. 


\subsubsection{Número de adultos de $1^{\text {a }}$ geração}

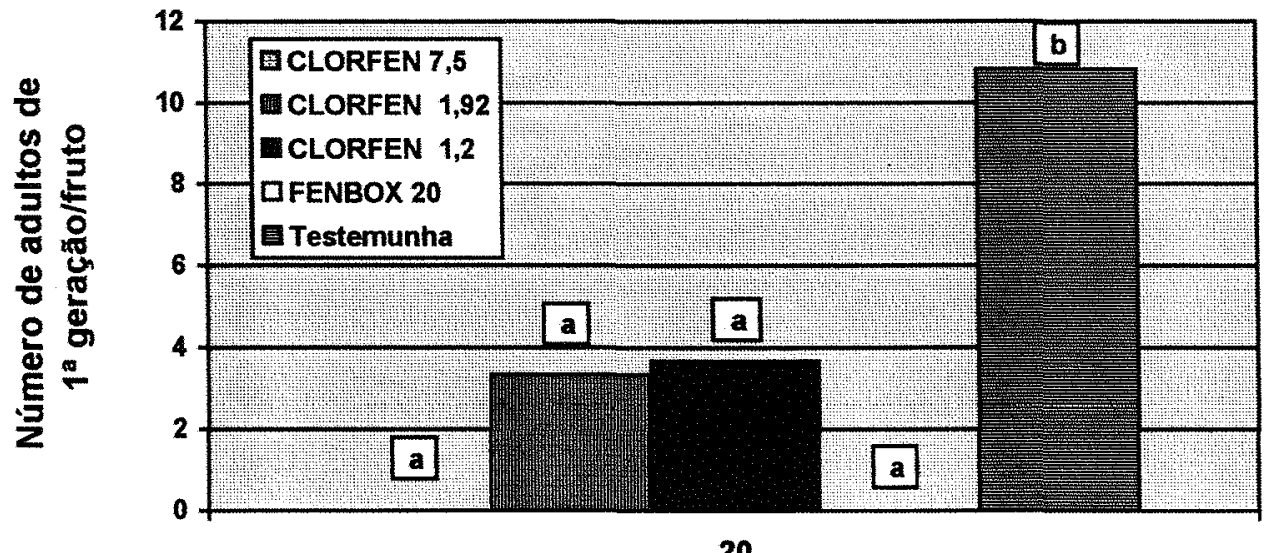

Dias após a aplicação

CLORFEN $=$ Clorfenapir g/100 L FENBOX $=0$ óxido de Fenbutatin g/100 L

Figura 20 - Número médio de adultos da $1^{\mathrm{a}}$ geração, bioensaio com pulverização através da Torre de Potter. Dados acompanhados da mesma letra não diferem estatisticamente ao nível de $5 \%$. As comparações entre os tratamentos foram realizadas em uma mesma data.

A interpretação desse parâmetro deve ser efetuada com cautela, pois assim que apareceram os adultos da primeira geração o bioensaio foi encerrado, sendo este número portanto pequeno, mas pode-se verificar que a testemunha diferiu estatisticamente de todos os demais tratamentos.

\subsection{Aplicação prática dos resultados obtidos nos três bioensaios.}

Além do desenvolvimento da metodologia que pode ser utilizada em bioensaios, os resultados mostram que as dosagens do clorfenapir necessárias para se obter um controle satisfatório do ácaro da leprose estão bem abaixo das recomendadas pela empresa fabricante. Evidentemente as condições de campo são diferentes das de laboratório onde foram desenvolvidos esses bioensaios, mas sabendo-se que $20 \%$ da dosagem recomendada do clorfenapir é suficiente para controlar o ácaro da leprose, levanta-se a hipótese de que as técnicas de pulverização e a época de controle de $B$. phoenicis devam ser melhor pesquisados, visando a maximização do controle das pulverizações convencionais de campo. $O$ objetivo final seria alcançar dosagens diferenciadas do produto de acordo com a infestação e a época do ano em que se efetua 
o controle. Comenale Neto et al. (1995), aplicaram diferentes acaricidas em épocas distintas do ano, sob vários níveis de infestação de B. phoenicis e mostraram que existe uma relação entre o nível de infestação do ácaro e o tempo que se conseguirá mantê-lo em nível abaixo do dano, em alguns períodos do ano.

Apesar dos resultados não serem totalmente uniformes para os três bioensaios testados, fica clara a necessidade do estabelecimento de uma relação entre nível de infestação, período de controle e até mesmo dosagem do produto a ser utilizada para se alcançar um controle satisfatório e economicamente viável de B. phoenicis. A preservação dos inimigos naturais, outro fator importante no controle do ácaro da leprose, é favorecida quando os intervalos entre as aplicações são maiores e as dosagens utilizadas são menores. A associação de todos esses parâmetros aliada a uma pulverização uniforme, que consiga cobrir toda a planta, são fatores determinantes no sucesso do controle do ácaro da leprose. 


\section{CONCLUSÕES}

A metodologia utilizada nos bioensaios, propiciou o desenvolvimento dos ácaros nos frutos de laranja, e a constatação da eficiência do clorfenapir no controle de Brevipalpus phoenicis.

A presença da mistura de gesso e areia tratada e não tratada com o clorfenapir não afetou os resultados finais de eficiência do acaricida.

Não ficou provada a ação ovicida, e nem esterilizante do clorfenapir sobre as fềmeas, tendo em vista que aquelas que sobreviveram, continuaram realizando a postura de ovos viáveis.

A dosagem de $3,00 \mathrm{~g}$ de clorfenapir/100 $\mathrm{L}$ proporcionou um controle satisfatório do ácaro da leprose, alcançando níveis de 90 a 100\%.

A dosagem de $1,92 \mathrm{~g}$ de clorfenapir/100 $\mathrm{L}$ foi a mais adequada para se avaliar os efeitos do clorfenapir na população remanescente dos ácaros. 
ANEXO: Análise da variância dos três bioensaos.

Tabela 1: Análise de variância do número de fêmeas mortas, bioensaio com aplicação do clorfenapir através do método de imersão.

\begin{tabular}{lccccc}
\hline \multicolumn{1}{c}{$\begin{array}{c}\text { Fontes de } \\
\text { Variação }\end{array}$} & GL & SQ & QM & F & Pr>F \\
\hline Dias & 3 & 243,7164 & 81,2388 & 71,63 & 0,0001 \\
Doses & 5 & 293,0778 & 58,6156 & 51,69 & 0,0001 \\
Dias x doses & 15 & 48,3464 & 3,2231 & 2,84 & 0,0005 \\
Resíduo & 208 & 235,8889 & 1,1341 & & \\
Total corrigido & 231 & 817,9310 & & & \\
\hline
\end{tabular}

Coeficiente de Variação: $\mathrm{CV}=30,57$

Tabela 2: Análise de variância do número de ovos, bioensaio com aplicação do clorfenapir através do método de imersão.

\begin{tabular}{lccccc}
\hline Fontes de variação & GL & SQ & QM & F & Pr>F \\
\hline Dias & 3 & 8,3832 & 2,7944 & 77,90 & 0,0001 \\
Doses & 5 & 5,1992 & 1,0399 & 28,99 & 0,0001 \\
Dias x doses & 15 & 1,2128 & 0,0808 & 2,25 & 0,0059 \\
Resíduo & 208 & 7,4618 & 0,0359 & & \\
Total corrigido & 231 & 22,2233 & & & \\
\hline Coeficiente de Variação: $\mathrm{CV}=14,3681$ & & &
\end{tabular}

Tabela 3: Análise de variância do número de larvas mortas, bioensaio com aplicação do clorfenapir através do método de imersão.

\begin{tabular}{lccccc}
\hline \multicolumn{1}{c}{$\begin{array}{c}\text { Fontes de } \\
\text { Variação }\end{array}$} & GL & SQ & QM & F & Pr>F \\
\hline Dias & 2 & 4,6616 & 2,3308 & 139,63 & 0,0001 \\
Doses & 5 & 0,4861 & 0,0972 & 5,82 & 0,0001 \\
Dias x doses & 10 & & 0,0501 & 3,00 & 0,0017 \\
Resíduo & 156 & 2,6040 & 0,0167 & & \\
Total corrigido & 173 & 8,3047 & & & \\
\hline Coeficiente de Variação: $\mathrm{CV}=14,4697$ & & &
\end{tabular}


Tabela 4: Análise de variância do número de larvas vivas, bioensaio com aplicação do clorfenapir através do método de imersão.

\begin{tabular}{lccccc}
\hline Fonte de Variação & GL & SQ & QM & Valor de F & Pr $>$ F \\
\hline Dias & 2 & 1,0900 & 0,5450 & 4,64 & 0,0110 \\
Doses & 5 & 7,2355 & 1,4471 & 12,33 & 0,0001 \\
Dias x doses & 10 & 5,2082 & 0,5208 & 4,44 & 0,0001 \\
Resíduo & 156 & 18,3079 & 0,1174 & & \\
Total corrigido & 173 & 32,2905 & & & \\
\hline Coeficiente de Variação: $\mathrm{CV}=34,3519$ & & & &
\end{tabular}

Tabela 5: Análise de variância do número de ninfas vivas, bioensaio de imersão, bioensaio com aplicação do clorfenapir através do método de imersão.

\begin{tabular}{lccccc}
\hline $\begin{array}{c}\text { Fontes de } \\
\text { Variação }\end{array}$ & GL & SQ & QM & F & Pr>F \\
\hline Dias & 1 & 0,0094 & 0,0094 & 0,13 & 0,7193 \\
Doses & 5 & 5,1965 & 1,0393 & 14,37 & 0,0001 \\
Dias x doses & 5 & 0,2269 & 0,0454 & 0,63 & 0,6791 \\
Resíduo & 106 & 7,6663 & 0,0723 & & \\
Total corrigido & 117 & 13,0721 & & & \\
\hline
\end{tabular}

Coeficiente de Variação: $\mathrm{CV}=28,6229$

Tabela 6: Análise de variância do número de fềmeas mortas, bioensaio de imersão com a mistura de gesso e areia tratada (GT) e não tratada (GNT) com o clorfenapir

\begin{tabular}{lccccc}
\hline Fontes de Variação & GL & SQ & QM & F & Pr $>$ F \\
\hline Doses & 2 & 6,5570 & 3,2785 & 18,52 & 0,0001 \\
Gesso & 1 & 2,6667 & 2,6667 & 15,06 & 0,0001 \\
Doses x gesso & 1 & 0,0034 & 0,0034 & 0,02 & 0,8899 \\
Dias & 3 & 23,7128 & 7,9043 & 44,64 & 0,0001 \\
Doses x dias & 6 & 1,1884 & 0,1982 & 1,12 & 0,3533 \\
Gesso x dias & 3 & 0,7237 & 0,2412 & 1,36 & 0,2560 \\
Doses x gesso x dias & 3 & 0,5247 & 0,1749 & 0,99 & 0,3999 \\
Resíduo & 175 & 30,9874 & 0,1771 & & \\
Total corrigido & 194 & 75,2616 & & & \\
\hline Coeficiente de Variação: $\mathrm{CV}=27,7857$ & & & &
\end{tabular}


Tabela 7: Análise de variância do número de ovos, bioensaio de imersão com a mistura de gesso e areia tratada (GT) e não tratada (GNT) com o clorfenapir

\begin{tabular}{lccccc}
\hline \multicolumn{1}{c}{ Fontes de variação } & GL & SQ & QM & F & Pr>F \\
\hline Doses & 2 & 19,9687 & 9,9843 & 25,78 & 0,0001 \\
Gesso & 1 & 0,8311 & 0,8311 & 2,15 & 0,1447 \\
Doses x gesso & 1 & 0,0858 & 0,0858 & 0,22 & 0,6384 \\
Dias & 3 & 56,1558 & 18,7186 & 48,33 & 0,0001 \\
Doses x dias & 6 & 11,1305 & 1,8550 & 4,79 & 0,0002 \\
Gesso x dias & 3 & 0,7973 & 0,2657 & 0,69 & 0,5616 \\
Doses x gesso x dias & 3 & 0,5346 & 0,1782 & 0,46 & 0,7105 \\
Resíduo & 175 & 67,7750 & 0,3873 & & \\
Total corrigido & 194 & 175,3342 & & & \\
\hline Coeficiente de Variação: CV $=23,7381$ & & & &
\end{tabular}

Tabela 8: Análise de variância do número de larvas mortas, bioensaio de imersão com a mistura de gesso e areia tratada (GT) e não tratada (GNT) com o clorfenapir

\begin{tabular}{lccccc}
\hline \multicolumn{1}{c}{ Fontes de Variação } & GL & SQ & QM & F & Pr>F \\
\hline Doses & 2 & 2,8985 & 1,4492 & 17,27 & 0,0001 \\
Gesso & 1 & 0,4562 & 0,4562 & 5,44 & 0,0208 \\
Doses x gesso & 1 & 0,0184 & 0,0184 & 0,22 & 0,6402 \\
Dias & 3 & 59,1684 & 19,7228 & 235,09 & 0,0001 \\
Doses x dias & 6 & 5,5163 & 0,91941 & 10,96 & 0,0001 \\
Gesso x dias & 3 & 0,7348 & 0,2449 & 2,92 & 0,0356 \\
Doses x gesso x dias & 3 & 0,1639 & 0,0546 & 0,65 & 0,5832 \\
Resíduo & 175 & 14,6814 & 0,0839 & & \\
Total corrigido & 194 & 93,6714 & & & \\
\hline Coeficiente
\end{tabular}

Coeficiente de Variação $=\mathrm{CV}=24,1156$ 
Tabela 9: Análise de variância do número de larvas vivas, bioensaio de imersão com a mistura de gesso e areia tratada (GT) e não tratada (GNT) com o clorfenapir

\begin{tabular}{lccccc}
\hline \multicolumn{1}{c}{ Fontes de Variação } & GL & SQ & QM & F & Pr>F \\
\hline Doses & 2 & 0,5160 & 0,2580 & 5,06 & 0,0073 \\
Gesso & 1 & 0,2706 & 0,2706 & 5,31 & 0,0224 \\
Doses x gesso & 1 & 0,0238 & 0,0238 & 0,47 & 0,4956 \\
Dias & 3 & 36,9841 & 12,3280 & 241,79 & 0,0001 \\
Doses x dias & 6 & 0,9964 & 0,1661 & 3,26 & 0,0046 \\
Gesso x dias & 3 & 0,2984 & 0,0995 & 1,95 & 0,1232 \\
Doses x gesso x dias & 3 & 0,0241 & 0,0080 & 0,16 & 0,9247 \\
Resíduo & 175 & 8,9226 & 0,0510 & & \\
Total corrigido & 194 & 50,8310 & & & \\
\hline Coeficiente de Variacão $=\mathrm{CV}=22,65053$ &
\end{tabular}

Tabela 10: Análise de variância do número de ninfas vivas, bioensaio de imersão com a mistura de gesso e areia tratada (GT) e não tratada (GNT) com o clorfenapir

\begin{tabular}{lccccc}
\hline Fontes de Variação & GL & SQ & QM & F & Pr $>$ F \\
\hline Doses & 2 & 4,4196 & 2,2099 & 6,07 & 0,0028 \\
Gesso & 1 & 0,0170 & 0,0170 & 0,05 & 0,8291 \\
Doses x gesso & 1 & 0,5694 & 0,5694 & 1,56 & 0,2128 \\
Dias & 3 & 165,8048 & 55,2683 & 151,79 & 0,0001 \\
Doses x dias & 6 & 12,7553 & 2,1259 & 5,84 & 0,0001 \\
Gesso x dias & 3 & 0,0499 & 0,0166 & 0,05 & 0,9870 \\
Doses x gesso x & 3 & 1,6704 & 0,5568 & 1,53 & 0,2086 \\
dias & & & & & \\
Resíduo & 175 & 63,7190 & 0,3641 & & \\
Total corrigido & 194 & 244,3691 & & & \\
\hline
\end{tabular}

Coeficiente de Variação $=\mathrm{CV}=23,8831$ 
Tabela 11: Análise de Variância do número de fềmeas mortas, bioensaio com pulverização do acaricida através da Torre de Potter

\begin{tabular}{|c|c|c|c|c|c|}
\hline Fontes de Variação & GL & SQ & $\mathrm{QM}$ & $\mathrm{F}$ & $\operatorname{Pr}>\mathrm{F}$ \\
\hline Dias & 3 & 93,6062 & 31,2020 & 28,99 & 0,0001 \\
\hline Doses & 4 & 229,6800 & 57,4200 & 53,35 & 0,0001 \\
\hline Dias $x$ doses & 12 & 36,8613 & 3,0718 & 2,85 & 0,0021 \\
\hline Resíduo & 97 & 5490,0000 & 56,5979 & & \\
\hline Total corrigido & 116 & 14745,6923 & & & \\
\hline \multicolumn{6}{|c|}{ Coeficiente de Variação $=\mathrm{CV}=36,7848$} \\
\hline \multicolumn{6}{|c|}{$\begin{array}{l}\text { Tabela 12: Análise de variância do número de ovos, bioensaio com pulverização d } \\
\text { acaricida através da Torre de Potter }\end{array}$} \\
\hline Fontes de variação & GL & SQ & QM & $\mathrm{F}$ & $\operatorname{Pr}>F$ \\
\hline Dias & 3 & 7181,0494 & 2393,6831 & 42,29 & 0,0001 \\
\hline Dosagem & 4 & 1325,5073 & 331,3768 & 5,85 & 0,0003 \\
\hline Dias $x$ doses & 12 & 639,6256 & 53,3021 & 0,94 & 0,5094 \\
\hline Resíduo & 97 & & & & \\
\hline Total corrigido & 116 & & & & \\
\hline
\end{tabular}

Coeficiente de Variação $=\mathrm{CV}=37,7255$ 


\section{REFERÊNCIAS BIBLIOGRÁFICAS}

ADDOR, R.W.; BABCOCK, T.J.; BLACK, B.C. et al. Insecticial pyrroles; discovery and overview. In: BAKER, D.R.; FENYES, J.G.; STEFFENS, J.J. Synthesis and chemistry of agrochemicals III. Washington: American Chemical Society, 1992. cap. 5, p. 283-297. (ACS Symposium Series, 504).

ALBUQUERQUE, F.A. de. Estudo da relação entre a verrugose da laranja doce (Elsinoe australis Bit. \& Jenk.) e o comportamento do ácaro da leprose Brevipalpus phoenicis (Geijskes) em citros (Citrus sinensis Osbeck). Jaboticabal, 1996. 93p. Dissertação (Mestrado) - Faculdade de Ciências Agrárias e Veterinárias, Universidade Estadual Paulista "Julio de Mesquita Filho".

ALBUQUERQUE, F.A. de; OLIVEIRA, C.A.L. de; BARRETO, M. Comportamento do ácaro Brevipalpus phoenicis (Geijskes, 1939) (Acari: Tenuipalpidae) em frutos de citros. In: OLIVEIRA, C.A.L. de, DONADIO, L.C. (Coord.) Leprose dos citros. Jaboticabal: FUNEP, 1995. p.77-90.

BARRETO, M.; PAVAN, A. Relação verrugose x leprose. In: OLIVEIRA, C.A.L. de, DONADIO, L.C. (Coord.) Leprose dos citros. Jaboticabal: FUNEP, 1995. p.6976.

BITANCOURT,A.A. A leprose dos citrus. O Biológico, v.6, n.2, p.39-45,1940. 
BITANCOURT, A.A. Estudos sobre a leprose dos Citros. Arquivos do Instituto Biológico, v.22, p.161-231, 1955.

BITANCOURT, A.A. A transmissão da leprose dos Citrus nas folhas e frutos. $\mathbf{O}$ Biológico, v.22, p.101-117, 1956.

BOARETTO, M.A.C.; CHIAVEGATO; L.G. Transmissão da leprose por ácaros Brevipalpus phoenicis (Geijskes, 1939) (Acari: Tenuipalpidae), temporariamente mantidos em hospedeiros intermediários, em condições de laboratório. Científica, v. 22, n. 1, p. $81-93,1994$.

BOARETTO, M.A.C.; CHIAVEGATO, L.G.; SILVA, C.A.D. Transmissão da leprose através de fềmeas de Brevipalpus phoenicis (Geijskes, 1939) (Acari: Tenuipalpidae) e de seus descendentes, em condições de laboratório. Científica, v.21, n.2, p.245$253,1993$.

CABRITA, J.R.M. Tratamento fitossanitário dos laranjais. Laranja, v.8, n. 1, p.47-50, 1987.

CALAFIORI, M. H; ALVAREZ, J.E; FERRAZ, J. et al. Controle do ácaro da leprose Brevipalpus phoenicis (Geijskes, 1939) em laranjeiras, Citrus spp., em duas regiões do estado de São Paulo. Ecossistema, v.11, p.53-60, 1986.

CHAGAS, C.M. A associação do ácaro Brevipalpus phoenicis (Geijskes) à mancha anular do cafeeiro. O Biológico, v.39, n.9, p.229-232, 1973.

CHAGAS, C.M.; ROSSETTTI, V. Transmissão experimental da leprose dos citros por meio de implantação de tecido foliar no caule. Fitopatologia Brasileira, v.5, p.392, 1980. 
CHIAVEGATO, L.G. Susceptibilidade de algumas espécies de ácaros fitófagos a alguns acaricidas e inseticidas em condições de laboratório. Piracicaba, 1972. 72p. Dissertação (Mestrado) - Escola Superior de Agricultura "Luiz de Queiroz", Universidade de São Paulo.

CHIAVEGATO, L.G. Biologia do ácaro Brevipalpus phoenicis em citros. Pesquisa Agropecuária Brasileira, v.21, n.8, p.813-816, 1986.

CHIAVEGATO, L.G. A leprose dos citros no estado de São Paulo. Laranja, n.8, v.1, p.7-18, 1987.

CHIAVEGATO, L.G.; KHARFAN, P.R. Comportamento do ácaro da leprose Brevipalpus phoenicis (G) (Acari: Tenuipalpidae) em citros. Anais da Sociedade Entomológica do Brasil, v.22, n.2, p.355-359, 1993.

CHIAVEGATO, L.G.; MISCHAN, N.M. Comportamento do ácaro Brevipalpus phoenicis (Geijskes, 1939) (Acari: Tenuipalpidae) em frutos de diferentes variedades cítricas. Científica, v.15, n.1/2, p.17-22, 1987.

CHIAVEGATO, L.G.; SALIBE, A.A. Prejuizos provocados pelo ácaro Brevipalpus phoenicis (Geijskes, 1939) em algumas variedades citricas. Laranja, v.2, n.2, p.174-175, 1981.

CHIAVEGATO, L.G.; MISCHAN, N.M.; SILVA, M.A. Prejuízos e transmissibilidade de sintomas da leprose pelo ácaro Brevipalpus phoenicis (Geijskes, 1939) Sayed, 1946 (Acari, Tenuipalpidae) em citros. Científica, v.10, n.2, p.265-271, 1982.

CHIAVEGATO, L.G.; TRINDADE, M.L.B.; NOGUEIRA, C.E.T. et al. Efeito de espalhante adesivo na eficiência de Hexythiazox no controle do ácaro Brevipalpus phoenicis G. (Acari: Tenuipalpidae) em citros. Anais da Sociedade Entomológica do Brasil., v.22, n.2, p.341-348, 1993. 
COLARICCIO, A. Virus da leprose dos citros. Laranja, v.17, n.1, p.273-274, 1996.

COMEnAle NETO, C.; YAMAMOTO, P.T.; GRAVENA, S.; et al. Período de controle do ácaro da leprose Brevipalpus phoenicis por acaricidas em diferentes níveis de infestação. Laranja, v.16, n.2, p. 251-261, 1995.

DENNEHY, T.J.; GRANNET, J.; LEIGH, T.F. Relevance of slide dip and residual bioassay comparisons to detection of resistence in spider mites. Journal of Economic Entomology, v.76, n.5, p.1225-1230, 1983.

FARLOW, R.A.; TREACY, M.F; MILLER, S.E.; et al. Efficacy of AC 303,630 against pest on cotton: Summary of 1989-90 field trial results. In: BELTWIDE COTTON PRODUCTION AND RESEARCH CONFERENCE, Beltwide, 1991. Proceedings. Beltwide: D.J. Herber, 1991. p.741-743.

FAWCETT, H.S. Citrus diseases and their control. New York: McGraw-Hill, 1936. $656 \mathrm{p}$.

FLECHTMANN, C.H.W.; OLIVEIRA, C.A.L. de; SANTOS, J.M. dos. Aspectos taxonômicos do ácaro da leprose Brevipalpus phoenicis. In: OLIVEIRA, C.A.L. de, DONADIO, L.C. (Coord.) Leprose dos citros. Jaboticabal: FUNEP, 1995. p.3136.

GONZALES, R.H. Revision of the Brevipalpus phoenicis complex with descriptions of new species from Chile and Thailand (Acarina, Tenuipalpidae). Acarologia, v.17, n.1, p.81-91, 1975.

GRAVENA, S. MIP citros: Avanços e inovação da citricultura brasileira. Laranja, v.13, n.2, p.635-691, 1992.

GRAVENA, S. Rotação de acaricidas no MIP - Citros: Menos desequilíbrio e resistência. Laranja, v.15, n.2, p.375-398, 1994. 
GRAVENA, S.; LARA, F.M. Efeito de alguns inseticidas sobre predadores entomófagos em citros. Anais da Sociedade Entomológica do Brasil, v.5, n.1,p.39-42, 1976.

GRAVENA, S.; BENETOLI, I.; MOREIRA, P.H.R. et al. Euseius citrifolius Denmark \& Muma predation on citrus leprosis mite Brevipalpus phoenicis (Geijskes) (Acari: Phytoseiidae: Tenuipalpidae). Anais da Sociedade Entomológica do Brasil, v.23, n.2, p.209-218, 1994.

GUIRADO, N. ; SILVÉRIO, J.L. Leprose e Declínio: problemas sérios da citricultura paulista. Laranja, v.13, n.2, p.541-552, 1992.

HARAMOTO, F.H. Biology and control of Brevipalpus phoenicis (Geijskes) (Acarina: Tenuipalpidae). Honolulu: Hawaii Agricultural Experimental Station, 1969. 63p. (Technical Bulletin, 68).

HATZINIKOLIS, E.N. The genus Brevipalpus in Greece (Acari: Teuipalpidae). Entomologia Hellenica, v.4, n.2, p.37-47, 1986.

HUNT, D.A. 2- arylpyrroles: novel uncouplers of oxidative phosphorylation. In: INTERNATIONAL SYMPOSIUM ON ADVANCES IN THE CHEMISTRY OF INSECT CONTROL, 3, Cambridge, 1993. Advances in the chemistry of insect control III. Cambridge: Royal Society of Chemistry, 1993. p.127-140.

KAMESWARAN, V. Insecticidal pyrroles: Modifications of Hantzsch synthesis to aryl trifluormethyl pyrroles. In: INTERNATIONAL SYMPOSIUM ON ADVANCES IN THE CHEMISTRY OF INSECT CONTROL, 3, Cambridge, 1993. Advances in the chemistry of insect control III. Cambridge: Royal Society of Chemistry, 1993. p.141-155. 
KENNEDY, J.N.S.; VAN IMPE, G; HANCE, T.; et al. Demecology of the false spider mite, Brevipalpus phoenicis (Geijskes) (Acari, Tenuipalpidae). Journal of Applied Entomology, v.120, n. 8, p.493-499, 1996.

KITAJMA, E.W; MÜLLER, G.W; COSTA, AN.S. Partículas baciliformes associadas à leprose dos citros. In: CONGRESSO BRASILEIRO DE FRUTICUltURA, 1, Campinas, 1971. Anais. Campinas: SBF, 1971, p.419-438.

KNORR, L.C. Etiological association of a Brevipalpus mite with Florida scaly bark of citrus. Phytopathology, v.40, p.15, 1950.

KNORR, L.C.; DENMARK, H.A. Injury to citrus by the mite Brevipalpus phoenicis. Journal of Economic Entomology, v.63, n.6, p.1996-1998, 1970.

KNORR, L.C.; DENMARK, H.A.; BURNETT, H.C. Ocorrency of Brevipalpus mites, leprosis and false leprosis on citrus in Florida. Florida Entomologist, v.51, n.1, p.11-17, 1968.

KOMATSU, S.S. Aspectos bioetológicos de Euseius concordis (Chanti) (Acari: Phytoseiidae) e seletividade de acaricidas convencionais nos citros. Piracicaba, 1988. 117p. Dissertação (Mestrado) - Escola Superior de Agricultura 'Luiz de Queiroz', Universidade de São Paulo.

KOMATSU, S.S.; NAKANO, O. Estudos visando o manejo da leprose em citros através do ácaro predador Euseius concordis (Acari: Phytoseiidae). Laranja, n.9, p. 125-146, 1988.

LAL, L. Biology of Brevipalpus phoenicis (Geijskes) (Tenuipalpidae: Acarina). Acarologia, v.20, n.1, p.97-101, 1978.

MANGLITZ, G.R.; CORY E.N. Biology and control of Brevipalpus australis. Journal of Economic Entomology, v.46, n.1, p.116-119, 1953. 
MITIDIERI, M.V.M.M. Efeito de piretróides sobre o ácaro rajado Tetranychus urticae Koch, 1836 (Acari: Tetranychidae). Piracicaba, 1990. 163p. Dissertação (M.S.) Escola Superior de Agricultura "Luiz de Queiroz", Universidade de São Paulo.

MORISHITA, F.S. Biology and control of Brevipalpus inornatus (Banks). Journal of Economic Entomology, v.47, n.3, p.449-456, 1954.

MUSUMECI, M.R.; ROSSETTI, V. Transmissão dos sintomas da leprose dos citros pelo ácaro Brevipalpus phoenicis. Ciência e Cultura, v.15, n.3, p.228, 1963.

MYAZAKI, I.; SUPLICY FILHO, N.; SAMPAIO, A.S. Comportamento do ácaro da leprose dos citros Brevipalpus phoenicis (Geijskes,1939) sob ação de acaricidas. O Biológico, v.48, n.1, p.21-24, 1982.

NAKANO, O. Novos produtos visando o controle do ácaro da leprose Brevipalpus phoenicis (Geijskes, 1939) (Acari: tenuipalpidae). Laranja, n.7, v.1, p. 33-44, 1986.

NAKANO, O. Rotatividade de ingredientes ativos em citros. In: OLIVEIRA, C.A.L. de, DONADIO, L.C. (Coord.) Leprose dos citros. Jaboticabal: FUNEP, 1995. p.189-194.

NAKANO, O; SANCHES, G.A.; ISHIDA, A.K. Redução da infestação do ácaro Brevipalpus phoenicis (Geijskes, 1939) em citros através do controle da verrugose. Laranja, v. 8, n.1, p.19-33, 1987.

OCHOA, R.; SALAS, L.A. The Genus Brevipalpus in Costa Rica (Acari: Tenuipalpidae). International Journal of Acarology, v. 15, n. 1, p.21-30, 1989.

OLIVEIRA, C.A.L. de. Flutuação populacional e medidas de controle do ácaro da leprose Brevipalpus phoenicis (Geijskes, 1939) em citros. Laranja, v.7. n.1, p.1$31,1986$. 
OLIVEIRA, C.A.L. de. Aspectos ecológicos de Brevipalpus phoenicis. In: OLIVEIRA, C.A.L. de, DONADIO, L.C. (Coord.) Leprose dos citros. Jaboticabal: FUNEP, 1995. p.37-48.

OLIVEIRA, C.A.L.; SILVA, J.R.T;; RIGOTTO, E.L. Controle do ácaro da leprose Brevipalpus phoenicis (Geijskes, 1939) (Acari: Tenuipalpidae) com produtos químicos na cultura do citros. Anais da Sociedade Entomológica do Brasil, v.12, n.2, p.221-234, 1983.

OMOTO, C. Resistência de Brevipalpus phoenicis (Acari: Tenuipalpidae) a acaricidas em pomares de citros do estado de São Paulo. Laranja, v. 17, n. 1, p. 283-285, 1996.

OOMEN, P.A. Studies on population dynamics of the scarlet mite, Brevipalpus phoenicis a pest of the in Indonesia. Mededdelingen Landbouwhogeschool Wageninggen, v.82, n.1, p.1-88, 1982.

PIJNACKER, L.P.; FERWERDA, M.A.; HELLE,W. Cytological investigations on the female and male reproductive system of the partenogenetic privet mite Brevipalpus obovatus Donnadieu (Phytoptipalpidae, Acari). Acarologia, v.22, n.2, p.157-163, 1981.

PRATES, H.S. Leprose dos citrus. Casa da Agricultura, v.6, n.1, p.9-13, 1984.

RAGA, A.; SATO,M.E.; CERÁVOLO, L.C.; et al. Ação de acaricidas sobre o ácaro da leprose Brevipalpus phoenicis (Geijskes, 1939) em pomar cítrico de Presidente Prudente, SP. Ecossistema, v.15, p.98-103, 1990.

REIS, P.R. de. Aspectos bioecológicos e seletividade de agroquímicos a Iphiseiodes zuluagai Denmark e Muma, 1972 (Acari: Phytoseiidae), 1996. 154p. Tese (Doutorado) - Escola Superior de Agricultura "Luiz de Queiroz", Universidade de São Paulo. 
RODRIGUES, J.C.V. Leprose dos citros: cito-histopatologia, transmissibilidade e relações com o ácaro vetor Brevipalpus phoenicis (Acari: Teniupalpidae) Piracicaba, 1995. 79 p. Dissertação (Mestrado) - Centro de Energia Nuclear na Agricultura, Universidade de São Paulo.

RODRIGUES, J.C.V.; NOGUEIRA, N.L.; PRATES, H.S. et al. Leprose dos citros: importância, histórico, distribuição e relações com o ácaro vetor. Laranja, v.15, n.2, p. 123-138, 1994.

ROESSING C.; SALIBE, A.A. Incidência da leprose em variedades cítricas. Ciência e Cultura, v.19, p.303, 1967.

ROSSETI, V.; MULER, G.W.; COSTA, A.S. Doenças de citros causadas por algas, fungos, bactérias e vírus. Campinas: Fundação Cargili, 1993. 84p.

ROSSETI, V.; NAKADAIRA, J.T.; CALZA, R. et al. Estudos sobre a clorose zonada dos citros. Arquivos do Instituto Biológico, v. 32, n.1, p.111-125, 1965.

SALVO FILHO, A. de. Notas sobre o tratamento fitossanitário em citros. Laranja, v. 18, n.1, p.155-163, 1997.

SALVO FILHO, A. de; SALVO, S. de. Tratamentos fitossanitários dos citros. Laranja, v.12, n.2, p.289-313, 1991.

SATO, M.E.; CERÁVOLO,L.C.; ROSSI,A.C. et al. Controle químico do ácaro da leprose Brevipalpus phoenicis (Geijskes,1939) (Acari: Teniupalpidae) em pomar cítrico de Presidente Prudente, Estado de São Paulo. Arquivos do instituto Biológico, v.58, p. 25-28, 1991. 
SATO, M.E.; RAGA, A.; CERÁVOLO,L.C. et al. Efeito de acaricidas sobre Brevipalpus phoenicis (Geijskes,1939) (Acari: Teniupalpidae) e ácaros predadores (Familia: Phytoseiidae) em citros. Revista Brasileira de Fruticultura, v.14, p.8793, 1992.

SCARPELLINI J.R.; NAKANO, O. Seletividade do ácaro predador Euseius spp. (Acari:Phytoseiidae) a alguns acaricidas na cultura dos citros. In: CONGRESSO BRASILEIRO DE ENTOMOLOGIA, 12., Belo Horizonte, 1989. Resumos. Belo Horizonte: SEB, 1989, p.575.

SCARPELLINI J.R.; SATO, M.E.; TAKEMATSU, A. P. et al. Efeito de acaricidas sobre o ácaro da leprose dos citros Brevipalpus phoenicis (Geijskes, 1939) no município de Bebedouro, São Paulo. Revista de Agricultura, v.66, p.183-192, 1991.

SUDOI, V. Evaluation of different acaricides for control of red crevice mite Brevipalpus phoenicis Geijskes (Acari: Teniupalpidae) infesting tea. Tropical Pest Management, v.36, n.4, p.349-352, 1990.

SUPLICY FILHO, N.; CINTRA, A.F.; MYAZAKI, I. et al. Comportamento do “ácaro da leprose" Brevipalpus phoenicis (Geijskes, 1939) em relação a alguns acaricidas na zona de Limeira. O Biológico, v. 43, p.21-4, 1977.

TEÓFILO SOBRINHO, J.; POMPEU JR., J.; CAETANO, A.A.; et al. Flutuação populacional do ácaro da leprose Brevipalpus phoenicis em pomares de citros na Estação Experimental de Limeira. In: CONGRESSO BRASLLEIRO DE FRUTICULTURA, 4., Salvador, 1977. Anais. Cruz das Almas: Sociedade Brasileira de Fruticultura, 1978. p.157-163.

TREACY, M.F.; MILLER, S.E.; BLACK, B.; et al. Uncoupling activity and pesticidal propeties of Pyrroles. Biochemical Society Transactions, v.22, p.244-247, 1994. 
TRINDADE, M.L.B.; CHIAVEGATO, L.G. Caracterização biológica dos ácaros Brevipalpus obovatus D., B. californicus B. e B. phoenicis G. (Acari: Tenuipalpidae). Anais da Sociedade Entomológica do Brasil, v.23, n.2, p.189$195,1994$.

VENDRAMINI, J.M.B.; NIVOLONI, R. F.; NAKANO, O. Ensaio visando o controle do ácaro da leprose (Brevipalpus phoenicis, Geijskes, 1939) dos citros. In: CONGRESSO BRASILEIRO DE ENTOMOLOGIA, 14. Piracicaba, 1993. Resumos. Piracicaba: Sociedade Entomológica do Brasil, 1993. p.440.

VIOLANTE NETTO, A. Causas do insucesso no controle dos ácaros dos pomares cítricos. Laranja, v. 8, n.1, p.51-69, 1987.

YAMAMOTO, P.T.; PINTO, A.S.; PAIVA, P.E.B.; GRAVENA, S. Seletividade de agrotóxicos aos inimigos naturais de pragas dos citros. Laranja, v.13, n.2, p.709755, 1992.

ZAHER, M.A.; WAFA, A.K. ; YOUSEF, A.A. Biology of Brevipalpus phoenicis (Geijskes), in Egypty. Bulletin of Society of Entomology Egypty, v.54, p.177-183, 1970. 